\title{
Artırılmış Gerçeklik Teknolojisi ile Öğrenmeye Yönelik Deneysel Çalışmalar: Sistematik Bir İnceleme
}

\section{Experimental Studies on Learning with Augmented Reality Technology: A Systematic Review}

\author{
Muzaffer ÖZDEMIR*
}

Öz: Son yıllarda, Artırılmış Gerçeklik (AG) teknolojisinin kullanımına yönelik araştırmalar, eğitim teknolojilerine yönelik araştırma eğilimleri arasında ilk sıralara doğru önemli adımlar atmaktadır. Gerçekleştirilen birçok çalışma, AG teknolojisinin öğrenmeyi ne derece artırdığı, ne tür avantajlar sağladığı, ne gibi zorlukları beraberinde getirdiği ve hangi eğitim alanları için uygun olduğu konusunda birçok soruya cevaplar aramıştır. Bu çalışmada, AG destekli öğrenme ortamlarını AG destekli olmayan diğer farklı öğrenme ortamları veya araçları ile çeşitli pedagojik özellikler açısından karşılaştıran deneysel çalışmaların sistematik olarak incelenmesi amaçlanmıştır. Bu bağlamda, incelenen çalışmalarda ele alınan 'eğitim alanı', 'hedef kitlenin eğitim seviyesi', 'bağımlı değişkenler', 'AG'nin öğrenmede etkililiği', 'AG'nin öğrenme ortamlarında kullanımına yönelik faydalar', 'AG uygulamalarında karşılaşılan zorluklar', 'kullanılan AG türü ve içeriği', 'ihtiyaç duyulan yazılımlar ve görüntüleme aygıtları' gibi faktörler değerlendirilmiştir. Araştırmanın amacı ve belirlenen özel kriterler doğrultusunda 2011-2016 yılları arasında yayımlanan ve SSCI'da taranan toplam 25 deneysel çalışma sistematik alanyazın inceleme metodu kullanılarak analiz edilmiştir. Sonuç olarak AG destekli öğrenme ortamlarının öğrencilerin öğrenme süreçlerini nasıl etkilediğine yönelik bulgular tartışılmıştır. Ayrıca öğrencilerin öğrenme süreçlerini destekleyecek yeni AG tasarımlarına yönelik bazı önerilerde bulunulmuştur.

Anahtar Kelimeler: Artırılmış gerçeklik, sanal gerçeklik, sistematik inceleme, eğitim teknolojileri

\begin{abstract}
In recent years, researches on Augmented Reality (AR) technologies are striving to take first place among research trends related to educational technologies. Until now, many studies sought answers for many questions about how much AR technology increases learning, what advantages it brings, what challenges it brings, and what training areas are appropriate. In this study; it is aimed to systematically review of experimental studies comparing AG-supported learning environments with other non-AGsupported different learning environments or tools in terms of various pedagogical features. In this context, factors, which are considered in the examined studies, such as 'education field', 'educational level of the target group', 'dependent variables', 'the effectiveness of AR in learning', 'benefits of using AR in learning environments', 'difficulties encountered in the implementations of AR', 'used AR types and contents', 'needed software' and 'displaying devices 'were evaluated. In accordance with the purpose of the research and the determined specific criteria, 25 experimental studies published between 2011 and 2016 and scanned at SSCI were analyzed by using a systematic literature review method. In conclusion, the findings of how AR-supported learning environments affect the learning process of students were discussed. In addition, some suggestions for new AR designs that will support the learning process of the students were presented. Keywords: Augmented reality, virtual reality, systematic review, education technology
\end{abstract}

\section{Giriș}

Okul sistemleri, kültürel ve teknolojik gelişmeler ile en iyi nasıl başa çıkabilecekleri konusunda mücadele ederken, bir yandan daha güçlü GPS (Global Positioning System; Küresel Konumlama Sistemi) özelliklerine, daha yüksek kalitede ağ sistemlerine ve daha güçlü işlem gücüne sahip aygıtların ortaya çıkması da muhtemel görünmektedir (Dunleavy, Dede ve Mitchell, 2009). Özellikle taşınabilir aygıtların teknolojik olarak gelişimi, öğrenme ortamları için eskisine göre daha fazla etkileşim imkânı sunabilen ve daha gerçekçi çoklu ortam öğelerinin hazırlanmasına

*Yrd.Doç.Dr., Çanakkale Onsekiz Mart Üniversitesi, Eğitim Fakültesi, Çanakkale-Türkiye, e-posta: mozdemir@comu.edu.tr 
imkan sağlamaktadır. A ̆ sistemlerinin hızlarındaki inanılmaz artış, bu çoklu ortam öğelerinin öğretim ortamlarında paylaşımını da büyük ölçüde kolaylaştırmıştır.

Mobil aygıtların ve kablosuz ağ teknolojilerinin hızlı bir şekilde yaygınlaşması, Artırılmış Gerçeklik (AG) ve Sanal Gerçeklik (SG) gibi yenilikçi teknolojilerin eğitim ortamlarında kullanımına yönelik firsatları da beraberinde getirmektedir. Bu yenilikçi teknolojiler, iki boyutlu (2D) veya üç boyutlu (3D) çoklu ortam içeriklerini gerçeklik, duyusal dalma (sensory immersion) ve etkileşim konularında oldukça farklı boyutlara taşımaktadır. AG ve SG teknolojilerinin sahip olduğu ve onları diğer bilgi ve iletişim teknolojilerinden ayıran benzersiz etkileşim özellikleri sayesinde, öğrencilerde geleneksel yöntemler ile gerçekleştirmenin mümkün olmadığı bir takım özel becerilerin gelişimine olanak sağlanabilir. Bu teknolojilerin sağladığı zengin ve etkileşimli içeriklerin geleneksel öğrenme ortamlarını ne derece zenginleştirebileceği ve böylece öğrenmeye ne derece katk1 sağlayabileceği, eğitimciler ve öğretim tasarımcıları için merak konusu olmuştur.

Teknolojiyi eğitim ortamlarına entegre ederken eğitsel mesajların öğrencilere etkili yollarla iletilmesinde fayda vardır (Özdemir, İzmirlive Sahin-İzmirli, 2016). Aksi taktirde bu adaptasyon, öğrencilerin öğrenmesini kolaylaştırmaktan ziyade negatif birtakım etkileri de beraberinde getirebilir (Leslie, Low, Jin ve Sweller, 2012). Bu bakımdan SG ve AG teknolojilerinin hangi yönlerinin ve ne tür bir içerik ile öğrenme için faydalı olabileceğini ortaya çıaran araştırmaların yapılmasına ihtiyaç duyulmaktadır (Richards ve Taylor, 2015). Böylece gerçekleştirilen bu çalışma ile, AG'nin eğitim ortamlarına entegrasyonunun hangi pedagojik özellikler bakımından etkili olabileceğine yönelik bulguları ortaya çıkarmak üzere literatürdeki bazı deneysel çalışmaların bir analizi sunulmuştur.

Son y1llarda AG teknolojilerine yönelik araştırmaların, eğitim teknolojilerindeki araştırma eğilimleri arasında ilk sıralarda yer aldığı söylenebilir. Bu teknolojinin öğrenme ve öğretim için sunduğu yeni olanaklar eğitimciler tarafindan zaman içerisinde kabul edilmeye başlamıştır (Erbaş ve Demirer, 2015). Gerçekleştirilen birçok çalışma AG teknolojilerinin öğrenmeyi ne derece artırdığı, ne tür avantajlar sağladığı, ne gibi zorlukları beraberinde getirdiği ve hangi eğitim alanları için uygun olduğuna yönelik birçok soruya cevaplar aramıştır. Bu çalışmaların çoğu elde ettikleri bulgulardan yola çıkarak AG teknolojisinin yakın gelecekte eğitim ortamlarının vazgeçilmez bir teknolojisi olabileceğini ileri sürmektedir.

\section{AG Tanımı ve Özellikleri}

AG, SG'nin bir varyasyonu olarak ortaya çıkmış olan (Azuma, 1997), 3D sanal nesneler ile gerçek dünya varlıklarının birlikteliğine ve gerçek zamanlı etkileşimlere imkân sağlayan (Azuma ve diğerleri, 2001), bağlam temelli dijital bilgi ile gerçek dünya ortamlarını dinamik olarak harmanlayabilen yenilikçi bir teknolojidir (Sommerauer ve Müller, 2014). Sanal nesneler ile gerçek dünya varlıklarının birlikteliği, AG kullanıcısının gerçeklik duygusunun artırmasına sebep olur (Bokyung, 2008). AG'nin faydaları, sadece görme duyusuna hitap etme özelliği ve kafaya monteli görüntüleme teknolojileri ile kullanılabilme yeteneği ile sınırlı tutulmamalıdır (Azuma, 1997). AG teknolojisinin etkileşim düzeyinin ve gerçeği temsil yeteneğinin oldukça iyi olması kullanıcısına 3D sanal nesnelere dokunma hissi ve varlık duygusu yaşatmakta ve bu sayede onun ilgi çekici ve özgün öğrenme deneyimleri yaşamasına olanak sağlamaktadır. Aynı zamanda AG'nin 3D sanal nesneleri gerçek dünya nesneleri ile gerçek zamanlı olarak bir arada bulundurabiliyor olmasının, soyut kavramları somutlaştırdığına ve bu sayede ögrenmeye pozitif katkılar sağladığına yönelik kanıtlar bulan çalışmalara (örn.,Chang ve diğerleri, 2014; Chang, Hou, Pan, Sung ve Chang, 2015; Huang, Chen ve Chou, 2016; Lin, Duh, Li, Wang ve Tsai, 2013; Sommerauer ve Müller, 2014; Tsai, Liu ve Yau, 2013) rastlamak mümkündür. AG sistemlerinde üç boyutlu modellerin yanı sıra metinler, görüntüler, videolar ve animasyonlar da kullanılabilmektedir (Yılmaz, 2016). Genelde AG sistemleri konum tabanlı ve görüntü tabanlı olmak üzere ikiye ayrılmaktadırlar (Chen ve Tsai, 2012). Konum tabanlı AG, GPS veya Wifi sistemleri ile belirlenen konum bilgisini kullanırken, görüntü tabanlı AG ise gerçek fiziksel nesnelerin bulunduğu ortama sanal nesneleri yerleştirmek üzere görüntü tanıma tekniklerini kullanır (Wojciechowski ve Cellary, 2013). AG'nin bu yenilikçi özellikleri, çoklu ortam destekli 
öğrenme materyallerinin geçmişe oranla daha üstün yeteneklere kavuşmalarına olanak sağlamiştır.

\section{Eğitimde AG Kullanımı}

AG teknolojisi, öğrencilerin fiziksel ortamlar ile etkileşimlerini artırmak ve onların öğrenmelerini kolaylaştırmak amacıyla, gerçek dünya varlıkları ve bu varlıklar üzerine bindirilebilen sanal bilgilerin (örn. metin, görüntüler, video klipler, sesler, üç boyutlu modeller ve animasyonlar) birleşimine olanak sağlar (Ke ve Hsu, 2015). Bu teknolojinin insanlık adına potansiyel faydaları, onun ilk olarak araştırmacılar tarafından öğrenmeye uygulanması ile ortaya çıkmaya başlamıştır (Ibáñez, Di-Serio, Villarán-Molina ve Delgado-Kloos, 2014). AG teknolojisi, öğrenmeyi teşvik etmek ve yapılandırmacı öğrenme ortamları oluşturmak bakımından eğitimde yeni firsatların ortaya çıkmasını sağlayabilir (Huang ve diğerleri, 2016). "Artırılmış gerçeklik teknolojisinin öğretim ve öğrenme için sunduğu yeni olanaklar zaman içerisinde eğitimcilerin de dikkatini çekmeye başlamıştır." (Demirer ve Erbaş, 2015). Eğitsel bir AG uygulaması gerçek dünyanın otantikliğini azaltmaksızın, öğrencilere daha esnek ve ilgi çekici öğrenme ortamları sağlayabilir (Lin ve diğerleri, 2013). AG teknolojisinin, öğrencilerde öğrenirken heyecan uyandırabilecek ve böylece öğrenmeye olan istekliliği artırmaya yardımcı olabilecek bir takım üstün yeteneklere sahip olduğu söylenebilir. Öyle ki bu teknolojinin öğrencilerde öğrenme istekliliğini ve motivasyonu artırıcı bir takım özelliklere sahip olduğuna dair kanıtlar bulan çalışmalara rastlamak mümkündür (Ibáñez ve diğerleri, 2014). Öğrencilerin öğrenme ortamında üç boyutlu sanal nesneleri gerçek dünya varlıkları ile bir arada görmeleri, onların daha önce deneyimlemedikleri bir heyecan yaşamalarına neden olabilir. Wu, Lee, Chang ve Liang (2013) çalışmalarında, AG'nin şu eğitsel faydalarına değinmiştir; içeriği üç boyutlu perspektiflerle sunarak görsel öğrenmeye yardımcı olma, öğrencileri işbirlikçi ve yerleşik öğrenmeye teşvik etme, görünmezi görünür kılma, formal ve informal öğrenme arasında bir köprü kurabilme. Bu teknoloji ile bilgi edinmek oldukça sezgiseldir. Bu yüzden AG teknolojisi öğrencilerin öğrenme süreçleri boyunca aktif gözlem yapabilmelerine, bu gözlemler boyunca çoklu varsayımları formulize edebilmelerine, gözlemlenen fenomenin geçerliliğini ve önerilen hipotezlerin rasyonalitesini dikkatli bir şekilde değerlendirebilmelerine ve birden fazla öneri hipotezini çürüttükten sonra nihai bir hipotez oluşturabilmelerine yardımcı olur (Chiang, Yang ve Hwang, 2014a).

Eğitsel AG uygulamaları öğrencilerin öğrenme performanslarını artırmalarına ve onların grup içi sosyal etkileşimler kurmalarına yardımcı olur(Lin ve diğerleri, 2013). Günümüzde en popüler eğitsel AG uygulamaları kitaplar (örn., Billinghurst, Kato ve Poupyrev, 2001) veya mobil oyunlar (örn., Bressler ve Bodzin, 2013) şeklinde karşımıza çıkmaktadır (Wei, Weng, Liu ve Wang, 2015). AG kitaplarında genelde görüntülenecek dijital AG nesneleri ile ilişkili tetikleyici görüntüler (marker) yer alır. Bu dijital nesneleri görüntüleyebilmek için tetikleyici görüntüler bir web kamera veya taşınabilir bir aygıtın (örn., mobil telefon veya tablet) kamerası tarafından algılanması gerekir. AG kitaplarının derslerde kullanımının, bazı soyut kavramların (örn., fizik dersinde elektrik alan konusu) somutlaştırılması bağlamında oldukça faydalı olabileceği öngörülmektedir. Mobil AG oyunları ise mobil teknolojilerin konum farkındalığının yanı sıra ilişkilendirme ve kişiselleştirme gibi avantajlarını kullanarak öğrencilerin bilimsel içerikleri otantik bağlamda deneyimlemelerine olanak sağlar (Bressler ve Bodzin, 2013). Bazı araştırmacılar (örn., Serino, Cordrey, McLaughlin ve Milanaik, 2016) bu oyunların fiziksel ve sanal dünyaları eş zamanlı olarak birleştirebilme özelliğinin, çocukların sosyal becerilerine ve eğitsel gelişimlerine katkı sağlayabileceğini ileri sürmektedirler.

AG, öğretim tasarımcıları ve eğitimcilerin mobil aygıtlar ile öğrenen öğrencilere, öğrenilen konu, kavram ve olaylar hakkında daha fazla düşünmelerine imkân sağlayan ortamlar oluşturmaları için birtakım firsatlar sunar. Eğitsel AG uygulamaları, Mayer (2002) tarafından ortaya atılan çoklu ortam tasarım prensiplerinden bazıları (zamansal ve mekânsal yakınlık, biçim/sunum türü ve dikkat çekme ilkesi) ile de oldukça yakından ilişkilidir (Santos ve diğerleri, 2014). Örneğin zamansal ve mekânsal yakınlık ilkeleri öğrenmenin artması için birbiri ile ilişkili öğretimsel öğeler arasındaki zamanın ve boşluğun en aza indirilmesi gerektiğini savunur (Mayer, 2005). AG uygulamalarında gerçek nesneler ile sanal nesneler eş zamanlı olarak bir arada 
sunulabildiğinden ve böylece ilgili görselleri arama ihtiyacı ortadan kalktığından dolayı AG tasarımları bu ilkeler ile pozitif bir uyum içerisindedir. Biçim/ sunum türü ilkesi ise; animasyon ya da resimler ile ilgili açıklamaların sözlü anlatım eşliğinde verilmesinin, sözlü anlatım yerine yazılı metin eşliğinde verilmesine göre öğrenmeyi kolaylaştırdığını ileri sürer (Moreno, 2006). AG uygulamalarında gerçek fiziksel nesneler üzerine bindirilen dijital nesneler, sözlü açıklamalar eşliğinde aynı anda verilebilmekte ve böylece bu tür uygulamaların tasarımları Biçim/sunum türü ilkesi ile de pozitif bir uyum içerisinde olabilmektedir. Son olarak dikkat çekme ilkesinde ise Mayer (2002), öğrenme materyallerine, anlatılan konu ile ilgili önemli öğeleri vurgulayan ipuçları eklendiğinde insanların daha iyi öğrenebileceğini iddia etmektedir. AG uygulamaları küresel konumlama sistemleri veya görsel tetikleyiciler sayesinde öğrenme ortamlarındaki öğrencilere konu ile ilgili gerekli yönlendirmeleri yapabilme yeteneğine sahiptir ve böylece bu ilke ile de uyum içerisindedir (Sommerauer ve Müller, 2015).

\section{Eğitimde AG Kullanımına Yönelik Analiz Çalıșmaları}

Alan yazın incelendiğinde, AG'nin eğitim ortamlarında kullanımına yönelik birkaç analiz çalışmasına rastlanmaktadır. Aşağıda bu çalışmalar ve inceleme sonuçları kısaca özetlenmiştir.

Bacca, Baldiris, Fabregat ve Graf (2014), eğitim ortamlarında AG üzerine literatür incelemesi yaparak, 2003-2013 arasında altı indeksli dergide (Computers and Education, Internet and Higher Education, British Journal of Educational Technology, Australasian Journal of Educational Technology, International Journal of Computer-Supported, Collaborative Learning) yayınlanan 32 makaleyi içerik analiz metodu kullanarak incelemişlerdir. Araştırmacılar inceleme çalışması ile aşağıdaki temel bulgulara ulaşmışlardır;

- Sağlık, öğretmen eğitimi ve tarım, AG açısından az keşfedilen araştırma alanlarıdır.

- AG'nin uygulama alanı çoğunlukla yükseköğretimdir.

- En çok kullanılan AG türü Marker ve konum tabanlı olanlardır.

- AG tabanlı eğitsel oyunlara yönelim vardır.

- AG ile ilgili olarak karşılaşılan zorluklar arasında; sanal ve gerçek nesnelerin birlikteliğini sürdürmek ve sanal bilgilere çok fazla dikkat harcamak üst sıralarda yer almaktadır.

- Motivasyon, öğrenci katılımı, olumlu tutum, etkileşim, iş birliği ve daha iyi öğrenme performansı elde etmede AG etkili olmaktadır.

- Öğrencilerin özel ihtiyaçlarına yönelen çalışmalar azınlıktadır.

- Çalışmaların çoğu 30 ile 200 katılımcı arasında gerçekleştirilmiştir.

- Çalışmalarda çoğunlukla karma değerlendirme yöntemleri tercih edilmiştir.

- En popüler veri toplama araçları, anketler ve mülakat yöntemleridir.

Dunleavy ve Dede (2014), formal ve informal öğrenme ortamlarında (okullar, üniversiteler, müzeler, parklar, hayvanat bahçeleri vb.) AG ile ilgili yapılan araştırma bulgularını özetledikleri çalışmalarında, öğrenme, öğretme ve öğretim tasarımı açısından AG ile ilişkili kolaylıklara ve sınırlılıklara değinmişlerdir. Literatür incelemesi sonucu araştırmacılar AG'nin kolaylıklarını şu şekilde ifade etmişlerdir:

- Öğrenci motivasyonunu artırır,

- Eğitimcilere işbirlikçi pedagojik teknikler ve deney tasarım yaklaşımları sunar,

- Çoklu bakış açıları sağlar,

- Probleme dayalı anlatım içinde bilgiyi bağlamsallaştırır,

- Verilen bir problemi çözmek için cihazlarda var olan uygulamalara ve internet gibi harici kaynaklara erişim imkânı sunar.

Araştırmacılar AG'nin sınırlılıklarına yönelik bulguları ise şu şekilde özetlemişlerdir; öğrencilerin bilişsel olarak yüklenmesi, çalışmalar sırasında genellikle öğrencileri bunaltması, öğretmenler ve tasarımcıların bakış açısından AG uygulamalarını yönetme zorluğu ve uyum sorunları.

Santos ve diğerleri (2014) yaptıkları meta analiz çalışmasında, K-12 seviyesinde IEEE Xplore'da yer alan ve AG ile öğrenme deneyimleri üzerine yapılan 87 araştırmayı incelemişler 
ve AG ile öğrenmenin birkaç tasarım boyutunu (görüntüleme donanımı, yazılım kütüphaneleri, içerik yazarlık çözümleri ve değerlendirme teknikleri) ele almışlardır. Araştırmacılar çalışmalarında AG'nin öğrenenler için şu üç doğal avantajı sağladığını belirtmiş̧lerdir; gerçek dünyada bilgi notları, bağlamsal görselleştirme ve görsel-dokunsal görselleştirme.

Bower, Howe, McCredie, Robinson ve Grover (2014), hem toplumda hem de eğitimde AG kullanımını inceledikleri çalışmada teknolojinin sağladığı pedagojik potansiyelleri tartışmışlardır. AG'nin desteklediği bazı pedagojik yaklaşımların; yapılandırmacı öğrenme, durumlu öğrenme, oyun-tabanlı öğrenme ve sorgulamaya dayalı öğrenme olduğunu belirtmişlerdir.

Satpute, Pingale ve Chavan (2015), eğitimsel amaçlar için AG’nin kullanışlılığını ve faydalarını keşfetmek amaciyla 2013-2014 yılları arası IEEE Xplore Digital Library, Science Direct, Springer ve Elseveir gibi veri tabanlarında yer alan makale ve sempozyum bildirilerini ele alan sistematik bir inceleme çalışması gerçekleştirmişlerdir. Çoğunlukla yükseköğretim üzerine odaklanan çalışmaları inceleyen araştırmacılar bu çalışmalardan ortaya çıkan sonuçlara göre AG'nin avantajlarını şu şekilde sıralamışlardır;

- Her yerde aynı anda öğrenme sağlar,

- Kendi kendine, işbirlikçi ve interaktif öğrenmeyi destekler,

- Ögrenmede katılımı artırır,

- Akademik başarıyı artırır,

- Öğrenmeden zevk almayı artırır.

Barsom, Graafland ve Schijven (2016), 2015 Ağustos'a kadar olan ve sağl1kla ilgili veri tabanlarını (PubMed, Embase, INSPEC ve Psych Info) tarayarak, tıp uzmanlarını eğitmek için kullanılan AG uygulamaları ile ilgili 27 makaleyi incelemişlerdir. Çalışmalardan elde ettikleri sonuçlara göre AG'nin harmanlanmış öğrenmeyi desteklediğini ve öğrencilere bilimsel ilgi kazandırdığını belirtmişlerdir. Araştırmacılar ayrıca ilgili literatürün bu tür kanıtları desteklemede yetersiz kaldığına de değinmiş̧lerdir.

Bu çalışma ile yukarıda özetlenen analiz çalışmalarından farklı olarak, AG destekli öğrenme ortamlarını, AG destekli olmayan diğer öğrenme ortamları ile karşılaştıran deneysel çalışmalar analiz edilmiş vebu yenilikçi teknolojinin öğrencilerin öğrenme süreçlerini (öğrenme stratejileri, öğrenme davranışları, öğrenme çıktıları vb.) nasıl etkilediğine yönelik bulgulara ulaşılmıştır. Ayrıca öğrenmeyi destekleyecek yeni AG tasarımlarına ilişkin bazı önerilerde bulunulmuştur.

\section{Araştırmanın Amacı}

$\mathrm{Bu}$ araştırmanın amacı; AG destekli öğrenme ortamlarını AG destekli olmayan diğer farklı öğrenme ortamları veya araçları ile çeşitli pedagojik özellikler açısından karşılaştıran deneysel çalışmaların sistematik bir incelemesini sunmaktır. Farklı kategorilerin analizi; ele alınan konu ile ilgili eğilimlerin, karşılaşılan zorlukların, sağladığı fırsatların, ileride yapılacak olan araştırmalar için tavsiyelerin ve geleceğe yönelik genel bir vizyonun ortaya çıkmasına imkân sağlayabilir (Bacca ve diğerleri, 2014). Bu bağlamda AG’nin öğrenme süreçlerini nasıl etkilediğine yönelik bulguları analiz etmek üzere şu faktörler ele alınmıştır; incelenen çalışmalarda ele alınan eğitim alanı, hedef kitle, bağımlı değişkenler, örneklem sayıları, AG'nin etkililiği, faydaları, uygulamada karşılaşılan zorluklar, kullanılan AG türü ve içeriği, ihtiyaç duyulan yazılımlar ve görüntüleme aygıtları.

\section{Araştırma Soruları}

AG'nin eğitimde kullanımına yönelik gerçekleştirilen deneysel çalışmalarda;

1. Ele alınan eğitim alanı, hedef kitle, bağımlı değişkenler ve AG'nin etkililiği nelerdir?

2. Örneklem sayısı ne kadardır? AG tabanlı öğrenme ortamları ile karşılaştırılan diğer öğrenme ortamları veya araçları nelerdir?

3. Uygulamada AG ile ilgili rapor edilen faydalar ve karşılaşılan zorluklar nelerdir?

4. AG uygulamalarının türleri nelerdir? Ne tür içerikler kullanılmıştır? 


\section{Yöntem}

Çalışmada "sistematik inceleme" metodu kullanılmıştır. "Sistematik bir alanyazın incelemesi, belirli bir araştırma sorusu, konu alanı veya bir ilgi fenomeni ile ilgili bütün erişilebilir araştırmaları tanımlamak, değerlendirmek ve yorumlamak anlamına gelmektedir" (Kitchenham, 2004). Çalışma Bacca ve diğerlerinin (2014) Kitchenham (2004)'ün çalışmasından derledikleri üç aşamalı bir yöntem ile gerçekleştirilmiştir; planlama, çalışmaları inceleme ve rapor etme. $\mathrm{Bu}$ yöntemler aşağıda alt başlıkları ile birlikte anlatılmıştır.

- Planlama,

- Dergilerin Seçimi,

- Çalışmaya dahil etme /hariç tutma kriterlerinin belirlenmesi,

- Kodlama ve Kategorilerin Belirlenmesi,

- İncelenecek Çalışmaların Belirlenmesi,

- Rapor etme.

\section{Planlama}

\section{Dergilerin seçimi}

İncelenecek makalelere ulaşmak üzere öncelikle akademik dergiler belirlenmiştir. Dergileri belirleme işlemi üç aşamalı gerçekleştirilmiştir. Birinci aşamada, Web of Science arama motoru kullanılarak bir dergi listesi elde edilmiştir. Íkinci aşamada ise birinci aşamada elde edilen listede yer alan dergilerden sadece Google Akademik Metriklerin "Eğitim teknolojileri" kategorisinde ilk sıralarda yer alan dergiler ele alınmıştır (Tablo 1). Üçüncü aşamada ise birinci aşamada elde edilen dergi listesinde yer alıp da ikinci aşamada elde edilen listede yer almayan fakat çalışma konusu ile ilgili yayın sayısı bakımından ilk sıralarda yer alan dergiler değerlendirme listesine ilave edilmiştir (Tablo 2). Böylece çalışmada ele alınan konu alanına ilişkin kategorilerde akademik metrikler bakımından ön sıralarda yer alan dergiler ile birlikte, yine ele alınan konuya ilişkin en çok yayın yapan dergilerin bir karması elde edilmiştir. Bu aşamalar aşağıda ayrıntıları ile anlatılmıştır.

Birinci aşama: Eğitimde AG kullanımına yönelik makalelere ulaşmak amacı ile ilk önce Web of Science arama motoru kullanmıştır. Tarama, Web of Science arama motorunun; eğitim, eğitsel araştırma (education, educational research), eğitim bilimi disiplinleri (education scientific disciplines), psikoloji eğitimi (psychology educational) ve özel eğitim (specialeducation) kategorilerinde gerçekleştirilmiştir. Alıntı indeksi olarak, metodoloji ve bilimsel açıdan güçlü makalelere ulaşmak amacı ile "Social Sciences Citation Index (SSCI)" seçilmiştir. Tarih aralığı ise son beş y1llık inceleme için 2011-2016 olarak belirlenmiştir. Web of Science veri tabanında yapılan makale taraması şu İngilizce sözcükler "veya" bağlacı kullanılarak gerçekleştirilmiştir; "augmented reality", "virtual reality", "virtual world", "virtual learning environment", "mixed reality", "virtual classroom".

İkinci aşama: Bu aşamada, ilk aşamada elde edilen listede yer alan akademik dergilerden, h5-endeks (Google Akademik Metrik) sıralamasında üst sıralarda yer alanlar belirlenmiştir (Tablo 1). Google Akademik Metrikler akademi dünyasında son yayınlanan makalelerin görünürlügüunü ve etkisini ortaya koyan metriklerdir. Çalışmada incelenecek dergiler Google Akademik Metriklerin "Sosyal Bilimler" kategorisinde yer alan "Eğitim teknolojileri” alt kategorisinden seçilmiştir.

Üçüncü aşama: Bu son aşamada ise, birinci aşamada elde edilen listede yer alıp da ikinci aşamada elde edilen listede yer almayan fakat Web of Science taraması sırasında çalışma konusu ile ilgili yayın sayısı bakımından üst sıralarda yer alan akademik dergiler değerlendirme listesine ilave edilmiştir (Tablo 2). Sonuç olarak değerlendirme için toplam 16 dergi belirlenmiştir. 
Tablo 1

Web of Science taraması ile elde edilen dergilerden Google Akademik h5-index siralamasında ilk 10 sirada yer alan ve SSCI tarafindan taranan dergiler.

\begin{tabular}{lc}
\hline Akademik Dergiler & h5-endeksi* $^{*}$ \\
\hline Computers \& Education & 88 \\
British Journal of Educational Technology & 48 \\
The Internet and Higher Education & 44 \\
Journal of Computer Assisted Learning & 41 \\
Journal of Educational Technology \& Society & 40 \\
The International Review of Research in Open and Distributed Learning & 36 \\
Educational Technology Researchand Development & 34 \\
Australasian Journal of Educational Technology & 33 \\
Distance Education & 28 \\
International Journal of Computer-Supported Collaborative Learning & 26 \\
*h5-endeks siralamast 29 Mayls 2016 yll itibariyle yapllmistr. &
\end{tabular}

Tablo 2

Web of Science tarama listesinde eğitimde AG kullanımı ile ilgili olarak yayın sayısı bakımından ilk siralarda yer alan akademik dergiler

\begin{tabular}{l}
\hline Dergi Ad1 \\
\hline Journal of Science Education \\
Interacti ve Learning Environments \\
IEEE Transactions on Learning Technologies \\
Eğitim ve Bilim-Educationand Science \\
Comunicar \\
Journal of Educational Computing Research \\
\hline
\end{tabular}

Seçilen makalelere ilişskin özel kriterler. Çalışmada tarih aralığı son beş yıllık inceleme için 20112016 olarak belirlenmiştir. Tarama sırasında bildiri, inceleme yazıları, editör materyalleri, notlar, toplantı özetleri, mektuplar, düzeltmeler, yeniden baskılar, kitap bölümü, haber öğeleri, tartışmalar ve biyografik öğeler inceleme dışı bırakılmıştır.

Kodlama ve kategorilerin belirlenmesi. Ele alınan makalelerden istenen verilerin toplanmas1 amacıyla, araştırmacı tarafından geliştirilen bir analiz tablosu kullanılmıştır. Makaleler ele alınan kriterlere göre sınıflandırılmış ve aşağıda belirtilen faktörlere göre elde edilen veriler bu analiz tablosuna kaydedilmiştir. Herhangi bir tutarsızlık durumunu araştırmacı, Çanakkale Onsekiz Mart Üniversitesi Bilgisayar ve Öğretim Teknolojileri Eğitimi Bölümü’nden iki alan uzmanı ile tartışarak çözme yolunu tercih etmiştir. Çalışmalara yönelik bulguları analiz etmek üzere ele alınan faktörler, çalışmanın beş araştırma sorusu (AS) ile ilişkili olarak aşağıdaki gibi belirlenmiştir;

- Birinci AS ile ilgili faktörler;

- Ele alınan eğitim alanı,

- Hedef kitle,

- Bağımlı değişkenler ve AG’nin etkililiği.

- İkinci AS ile ilgili faktörler;

○ Örneklem sayıları,

- AG tabanlı uygulamalar ile karşılaştırılan, diğer öğrenme ortamları veya araçları.

- Üçüncü AS ile ilgili faktörler;

- AG'nin faydaları

- Uygulamada karşılaşılan zorluklar.

- Dördüncü AS ile ilgili faktörler; 
○ AG'nin türü,

- AG içeriği,

- AG içeriğinin hazırlanmasında ihtiyaç duyulan yazılım(lar),

○ AG içeriğini görüntüleme aygıtları.

\section{Bulgular}

\section{İncelemek Üzere Belirlenen Çalışmalar}

Daha önce üzerinde durulan kriterler doğrultusunda Mayıs 2016'ye kadar yayınlanmış olan toplam 497 makaleye ulaşılmıştır. Bu makalelerin özetleri değerlendirildikten sonra sadece 51'inin eğitimde AG kullanımı ile ilgili yapılan çalışmalar olduğu tespit edilmiştir (Tablo 3). Tablo 3'den görüldüğü üzere ele alınan çalışmalarda 2014 yılına kadar artış, bu yıldan itibaren ise küçük bir düşüş yaşanmıştır. Ayrıca bu çalışmaların en çok Computers \& Education $(\% 33,33)$ dergisinde yayınlandığı görülmektedir. Bunu sırası ile Interactive Learning Environments $(\% 13,73)$, British Journal of Educational Technology (\%11,76) ve Journal of Science Educationand Technology $(\% 9,62)$ dergileri takip etmektedir.

Tablo 3

Ele alınan kriterlere göre belirlenen çalışmaların akademik dergilere ve yıllara göre dağılımı

\begin{tabular}{|c|c|c|c|c|c|c|c|c|}
\hline \multirow[b]{2}{*}{ Akademik Dergiler } & \multicolumn{6}{|c|}{ Çalışmaların yıllara göre dağglımı } & \multirow[b]{2}{*}{$\begin{array}{l}\text { Toplam } \\
\text { (f) }\end{array}$} & \multirow[b]{2}{*}{$\begin{array}{l}\text { Yüzde } \\
(\%)\end{array}$} \\
\hline & 2011 & 2012 & 2013 & 2014 & 2015 & 2016 & & \\
\hline Computers \& Education & 1 & 1 & 7 & 6 & 1 & 1 & 17 & 33,33 \\
\hline $\begin{array}{l}\text { British Journal of } \\
\text { EducationalTechnology }\end{array}$ & - & - & 4 & - & & 2 & 6 & 11,76 \\
\hline Internet and Higher Education & - & - & - & - & 1 & - & 1 & 1,96 \\
\hline $\begin{array}{l}\text { Journal of Computer Assisted } \\
\text { Learning }\end{array}$ & - & - & 1 & - & & - & 1 & 1,96 \\
\hline $\begin{array}{l}\text { Educational Technology \& Society } \\
\text { The International Review of }\end{array}$ & - & - & - & 1 & 1 & - & 2 & 3,92 \\
\hline $\begin{array}{l}\text { Research in Open and Distributed } \\
\text { Learning }\end{array}$ & - & - & - & - & - & - & - & 0,00 \\
\hline $\begin{array}{l}\text { Educational Technology Research } \\
\text { And Development }\end{array}$ & - & - & - & - & 1 & 1 & 2 & 3,92 \\
\hline $\begin{array}{l}\text { Australasian Journal of } \\
\text { EducationalTechnology }\end{array}$ & - & - & - & - & - & - & - & 0,00 \\
\hline Distance Education & - & - & - & - & - & - & - & 0,00 \\
\hline $\begin{array}{l}\text { International Journal of Computer- } \\
\text { Supported Collaborative Learning }\end{array}$ & - & 2 & - & - & - & - & 2 & 3,92 \\
\hline $\begin{array}{l}\text { Journal of Science Education and } \\
\text { Technology }\end{array}$ & - & 1 & - & 1 & 2 & 1 & 5 & 9,80 \\
\hline Interactive Learning Environments & - & 1 & - & - & 2 & 4 & 7 & 13,73 \\
\hline $\begin{array}{l}\text { IEEE Transactions on Learning } \\
\text { Technologies }\end{array}$ & - & - & - & 3 & - & 1 & 4 & 7,84 \\
\hline $\begin{array}{l}\text { Eğitim ve Bilim } \\
\text { Educationand Science }\end{array}$ & - & - & - & 1 & - & - & 1 & 1,96 \\
\hline Comunicar & - & - & - & & 1 & - & 1 & 1,96 \\
\hline $\begin{array}{l}\text { Journal of Educational Computing } \\
\text { Research }\end{array}$ & - & - & - & 1 & - & - & 1 & 1,96 \\
\hline Environmental Education Research & - & - & - & - & 1 & - & 1 & 1,96 \\
\hline Toplam & 1 & 5 & 12 & 13 & 10 & 10 & 51 & 100 \\
\hline
\end{tabular}

Araştırmanın amacı ve belirlenen özel kriterler doğrultusunda, yukarıda verilen 51 makale arasından, AG teknolojisi ile desteklenmiş öğrenme ortamlarını, AG destekli olmayan diğer 
öğrenme ortamları veya araçları ile kıyaslayan 25 deneysel çalışma incelemek üzere belirlenmiştir (Tablo 4). Burada amaç, AG’nin diğer farklı öğrenme ortamlarına/ araçlarına göre etkililiğini çeşitli pedagojik açılardan değerlendirmektir. Tablo 4'den görüldüğü üzere çalışmada ele alınan deneysel çalışmaların \%44'ünün Computers \& Education dergisinde yayınlandığı, bunu sırası ile Interactive Learning Environments (\%24) ve Journal of Science Educationand Technology (\% 12) dergilerinin izlediği görülmektedir.

Tablo 4

İncelenmek üzere belirlenen deneysel çalışmaların akademik dergilere ve yıllara göre dağılımı

\begin{tabular}{|c|c|c|}
\hline Akademik Dergiler & Deneysel Çalışmalar (f) & Yüzde (\%) \\
\hline Computers \& Education & 11 & 44,00 \\
\hline British Journal of Educational Technology & 1 & 4,00 \\
\hline Internet and Higher Education & 1 & 4,00 \\
\hline Journal of Computer Assisted Learning & 0 & 0,00 \\
\hline Educational Technology \& Society & 2 & 8,00 \\
\hline Educational Technology Research and Development & 0 & 0,00 \\
\hline Journal of Computer-Supported Collaborative Learning & 1 & 4,00 \\
\hline Journal of Science Education and Technology & 3 & 12,00 \\
\hline Interactive Learning Environments & 6 & 24,00 \\
\hline IEEE Transactions on Learning Technologies & 0 & 0,00 \\
\hline Eğitim ve Bilim- Education and Science & 0 & 0,00 \\
\hline Comunicar & 0 & 0,00 \\
\hline Journal of Educational Computing Research & 0 & 0,00 \\
\hline Environmental Education Research & 0 & 0,00 \\
\hline Toplam & 25 & 100 \\
\hline
\end{tabular}

Çalışmalarda Ele Alınan Ĕ̆itim Alanı, Hedef Kitle ve Bă̆ımlı Değişkenler

Tablo 5'den görüldüğü üzere incelenen deneysel çalışmaların çoğunlukla Doğa bilimleri, matematik ve istatistik eğitim ve öğretim alanında yoğunlaştığ $(\% 56)$ görülmektedir. Bu çalışmalar aşağıdaki alt bilim dalları ile ilişkili gerçekleştirilmiş̧tir;

- Alt1 çalışma (Chen ve Wang, 2015; Hsiao, Chen ve Huang, 2012; Ibáñez ve diğerleri, 2014; Lin ve diğerleri, 2013; Wang, Duh, Li, Lin ve Tsai, 2014; Zhang, Sung, Hou ve Chang, 2014) Fizik,

- Altı çalışma (Chang, Chung ve Huang, 2016; Chang, Hsu ve Wu, 2016; Chiang ve diğerleri, 2014a; Chiang ve diğerleri, 2014b; Huang ve diğerleri, 2016; Hsiao, Chang, Lin ve Wang, 2016) Ekolojik Çevre,

- Bir çalışma (Wojciechowski ve Cellary, 2013) Kimya ve

- Bir çalışma (Lin ve diğerleri, 2015) ise Matematik.

Ele alınan deneysel çalışmaların \%16'sıSosyal bilimler, gazetecilik ve enformasyon ana eğitim alanı ile ilgili gerçekleştirilmiştir. Bu çalışmalar arasından;

- Ǘç çalışma (Chang ve diğerleri, 2014; Yoon, Elinich, Wang, Steinmeier ve Tucker, 2012; Sommerauer ve Müller, 2014) Müze Çalışmaları ve

- Bir çalışma (Chen ve Tsai, 2012) ise Kütüphane çalışmaları ile ilgilidir.

Tabloda belirtilen diğer eğitim ve öğretim alanları ile ilgili gerçekleştirilen çalışmalara ait oranlar ise şu şekildedir; Mühendislik, Imalat ve Inş̧aat (Chang ve diğerleri, 2015; Gavish ve diğerleri, 2015; Liou, Bhagat ve Chang, 2016) \%12, Sanat ve beşeri bilimler(Wei ve diğerleri, 2015; DiSerio, Ibáñez ve Kloos, 2013) \%8, Ĕgitim (Ke ve Hsu, 2015) \%4 ve Hizmetler ise (Tsai ve diğerleri, 2013) \%4 oranındadır. Bunların yanı sıra incelenen deneysel çalışmalar arasında Işletme, Yöneticilik ve Hukuk, Bilgi ve İletişim Teknolojileri, Tarım, Ormancılık, Balıkçılık ve Veterinerlik ve Sağllkve Sosyal Yardımlaşma eğitim ve öğretim alanları ile ilişkili gerçekleştirilen çalışmalara rastlanmamıştır. 
Tablo 5

İncelenmek üzere belirlenen deneysel çalışmalarda ele alınan eğitim-öğretim alanları

\begin{tabular}{|c|c|c|}
\hline Eğitim ve öğretim alanları* & Çalışma Sayısı (f) & Yüzde $(\%)$ \\
\hline $\begin{aligned} \text { Doğa Bilimleri, Matematik ve İstatistik } \\
\text { - } \\
\text { - } \\
\text { - } \text { Matematik (6) } \\
\text { - } \text { Kimya (1) } \\
\text { - } \text { Biyoloji (0) } \\
\text { Ekoloji (6) }\end{aligned}$ & 14 & 56,00 \\
\hline $\begin{array}{l}\text { Sosyal bilimler, gazetecilik ve enformasyon } \\
\text { - Kütüphane Çalışmaları (1), } \\
\text { - Müze çalışmaları (3) }\end{array}$ & 4 & 16,00 \\
\hline $\begin{array}{l}\text { Mühendislik, İmalat ve İnşaat } \\
\text { - Endüstriyel bakım ve montaj eğitimi (1) } \\
\text { - Haritacıllk (1) } \\
\text { - Kimya Mühendisliği (1) }\end{array}$ & 3 & 12,00 \\
\hline $\begin{array}{l}\text { Sanat ve beşeri bilimler } \\
\text { - İç Tasarım (1), } \\
\text { - Güzel Sanatlar (1) }\end{array}$ & 2 & 8,00 \\
\hline $\begin{array}{ll}\text { Eğitim } & \\
\text { - } & \text { Erken çocukluk eğitimi }(0) \\
\text { - } & \text { Teknolojik pedagojik alan bilgisi (1) }\end{array}$ & 1 & 4,00 \\
\hline $\begin{array}{l}\text { Hizmetler } \\
\qquad \quad \text { Nükleer Kaza Eğitimi (1) }\end{array}$ & 1 & 4,00 \\
\hline İşletme, Yöneticilik ve Hukuk & 0 & 0,00 \\
\hline Bilgi ve İletişim Teknolojileri & 0 & 0,00 \\
\hline Tarım, Ormancılık, Balıkçılık ve Veterinerlik & 0 & 0,00 \\
\hline Sağlık ve Sosyal Yardımlaşma & 0 & 0,00 \\
\hline Toplam & 25 & 100,0 \\
\hline
\end{tabular}

*UNESCO Institute for Statistics'e (2015) göre belirlenmiştir.

Tablo 6'da,incelenen çalışmalara ait katılımcıların eğitim sevileri yer almaktadır. Tablodan görüldüğü üzere, çalışmalar çoğunlukla ortaögretim (\%36), lisans (\%24) ve ilköğretim (\%20) seviyelerindeki katılımcılarla gerçekleştirilmiştir. Diğer taraftan incelenen çalışmalar arasından hiçbirinin lise (\%0), ön lisans (\%0), yüksek lisans ve doktora (\%0) seviyelerindeki katılımcılar ile gerçekleştirilmediği görülmektedir.

Tablo 6

İncelenmek üzere belirlenen deneysel çalışmalarda katılımcıların eğitim seviyeleri

\begin{tabular}{lcl}
\hline Hedef Kitlenin Eğitim Seviyeleri* & Çalışma Sayısı (f) & Yüzde (\%) \\
\hline Erken çocukluk dönemi eğitsel gelişim & 2 & 8,00 \\
Illköğretim & 5 & 20,00 \\
Ortaöğretim & 9 & 36,00 \\
Lise & 0 & 0,00 \\
Ön Lisans & 0 & 0,00 \\
Lisans veya dengi seviye eğitim & 6 & 24,00 \\
Yüksek lisans veya dengi seviye eğitim & 0 & 0,00 \\
Doktora veya dengi seviye eğitim & 0 & 0,00 \\
Karma Eğitim & 1 & 4,00 \\
Informal Öğrenme & 2 & 8,00 \\
\hline \multicolumn{2}{c}{ Toplam } \\
\hline
\end{tabular}

* UNESCO Institute for Statistics (2015)'e göre belirlenmiştir. 
Tablo 7'de,incelenen deneysel çalışmalarda ele alınan bağımlı değişkenlerin yanı sıra bu bağımlı değişkenleri araştıran ve etkili bulan çalışmalara ait sıklık değerleri verilmektedir. Bir çalışma birden fazla bağımlı değişken ile çalışmayı tercih edebildiğinden dolayı, tabloda verilen bazı bağımlı değişkenler birden fazla çalışma için de belirtilmiş olabilmektedir. Tablo 7 incelendiğinde, AG'nin öğrenmede etkisinin en çok araştırıldığı bağımlı değişkenin öğrenme performansı $(\mathrm{n}=19)$ olduğu görülmektedir. Bunun yanı sıra incelenen çalışmaların çoğu $(\mathrm{n}=13)$ AG'nin öğrenme performansı bağlamında etkili olduğunu bulmuştur. İncelenen çalışmalar arasında bağımlı değişken olarak motivasyonu ele alanların tamamı (n=5) AG'nin motivasyon bağlamında etkili olduğu sonucuna ulaşmıştır. Tabloda sayıca dikkat çeken diğer iki bağımlı değişken ise akış deneyimi (n=3) ve tutumdur (3). Akış deneyimini bağımlı değişken olarak alan tüm çalışmalar, AG teknolojisini bu değişken üzerinde etkili bulurken tutum üzerine sadece bir çalışma AG'yi etkili bulmuştur. Tabloda listelenen diğer bağımlı değişkenler üzerinde AG'nin etkililiğini ele alan çalışmaların azınlıkta olduğu göze çarpmaktadır.

Tablo 7

İncelenmek üzere belirlenen deneysel çalışmalarda bağımlı değişkenler

\begin{tabular}{lcc}
\hline Bağımlı değişkenler & $\begin{array}{l}\text { Bağımlı değişken } \\
\text { üzerinde AG etkisini } \\
\text { araştıran çalışma sayısı }\end{array}$ & $\begin{array}{l}\text { Bağımlı değişken } \\
\text { üzerinde AG'yi etkili } \\
\text { bulan çalışma sayısı }\end{array}$ \\
\hline Öğrenme Performansı & 19 & 13 \\
Motivasyon & 5 & 5 \\
Akış Deneyimi & 3 & 3 \\
Tutum & 3 & 1 \\
Davranış biçimleri & 2 & 1 \\
Duygusal Etki & 1 & 1 \\
Eğitim Süresi & 2 & 2 \\
Kabullenme & 2 & 1 \\
Algılanan kullanışlılık (fayda) & 2 & 1 \\
Algılanan kullanım kolaylığ 1 & 1 & 1 \\
Bilişsel Kazanç & 1 & 1 \\
Yaratıcılık Düzeyi & 1 & 1 \\
Mekân duygusu etkisi & 1 & 1 \\
Müfredat özelliklerine ilişkin algı & 1 & - \\
Bilişsel Stil & 1 & - \\
Mücadele beceri algiları & 1 & - \\
Teknolojik pedagojik alan bilgisi & 1 & - \\
Uzamsal Yetenek & 1 & \\
\hline
\end{tabular}

İncelenen Çalışmalarda Örneklem Sayıları

Tablo 8'de, ele alına çalışmalarda tercih edilen örneklem sayıları yer almaktadır. Tablo incelendiğinde 0-29 arası örneklem sayısı ile çalışan iki, 30-59 arası örneklem sayısı ile çalışan 10, 60-99 arası örneklem sayısı ile çalışan altıve 100 üzeri örneklem sayısı ile çalışan yedi deneysel araştırmanın olduğu görülmektedir.

\section{AG Teknolojisinin Öğrenme Bağlamında Karşılaştırıldı̆̆ Diğer Ortamlar/ Araçlar}

Tablo 8'de, ele alınan çalışmalarda deney (AG destekli) ve kontrol (AG destekli olmayan) gruplarına ait öğrenme ortamları/araçları verilmiştir. Tablo incelendiğinde AG'nin etkililik bağlamında karşılaştırıldığı diğer öğrenme ortamları/araçları arasında, geleneksel öğrenme ortamları(örn., insan rehberli, yüz yüze, çoklu ortam destekli, PowerPoint destekli, video/film gösterimleri ile desteklenmiş, web tabanl1, 2D simülasyon destekli ve bilgisayar destekli) sayı bakımından ilk sırada yer almaktadır. Bunların yanı sıra üç çalışma mobil öğrenmeyi, iki çalışma simülasyon tabanlı öğrenmeyi, bir çalışma ise e-Maps tabanlı öğrenmeyi AG tabanlı öğrenme ortamları ile karşılaştırmayı tercih etmiştir. 
Tablo 8

İncelenmek üzere belirlenen deneysel çalışmalarda örneklem sayısı, deney ve kontrol grupları

\begin{tabular}{|c|c|c|c|}
\hline Çalışmalar & $\begin{array}{c}\text { Örneklem } \\
\text { sayis1 }\end{array}$ & Deney Gurubu & Kontrol Gurubu \\
\hline $\begin{array}{l}\text { Huang ve diğerleri } \\
\text { (2016) }\end{array}$ & 21 & AG Tabanlı öğrenme & $\begin{array}{l}\text { İnsan rehberli geleneksel } \\
\text { öğrenme }\end{array}$ \\
\hline $\begin{array}{l}\text { Chang ve diğerleri } \\
\text { (2016a) }\end{array}$ & 45 & AG Tabanlı öğrenme & $\begin{array}{l}\text { İnteraktif Simülasyon Tabanlı } \\
\text { Öğrenme }\end{array}$ \\
\hline $\begin{array}{l}\text { Chang ve diğerleri } \\
(2016 b) \text {. }\end{array}$ & 55 & AG Tabanlı öğrenme & Video tabanlı öğrenme \\
\hline $\begin{array}{l}\text { Liouve diğerleri } \\
\text { (2016) }\end{array}$ & 94 & $\begin{array}{l}\text { Artırılmış Gerçeklik, Sanal } \\
\text { Gerçeklik ve bulut tabanlı } \\
\text { ögrenme }\end{array}$ & $\begin{array}{l}\text { İnsan rehberli geleneksel } \\
\text { öğrenme }\end{array}$ \\
\hline $\begin{array}{l}\text { Hsiao ve diğerleri } \\
\text { (2016) }\end{array}$ & 64 & AG tabanlı öğrenme & Çoklu Ortam ile öğrenme \\
\hline $\begin{array}{l}\text { Wei ve diğerleri } \\
\text { (2015) }\end{array}$ & 33 & AG tabanlı öğrenme & $\begin{array}{l}\text { PowerPoint ile geleneksel } \\
\text { öğrenme }\end{array}$ \\
\hline Ke ve Hsu, (2015) & 40 & Mobil AG uygulaması & $\begin{array}{l}\text { Mobil medya tabanlı } \\
\text { uygulama }\end{array}$ \\
\hline $\begin{array}{l}\text { Chang ve diğ erleri } \\
(2015)\end{array}$ & 87 & AG tabanlı yönlendirme & $\begin{array}{l}\text { - Sesli yönlendirme } \\
\text { - Sesli yönlendirmesiz }\end{array}$ \\
\hline Chen ve Wang (2015) & 144 & AG tabanlı kapsamlı talimatlar & $\begin{array}{l}\text { PowerPoint ile geleneksel } \\
\text { öğrenme }\end{array}$ \\
\hline $\begin{array}{l}\text { Gavish ve diğerleri } \\
\text { (2015) }\end{array}$ & 40 & AG platformuyla eğitim & $\begin{array}{l}\text { Geleneksel eğitim ve film } \\
\text { gösterimi }\end{array}$ \\
\hline $\begin{array}{l}\text { Lin ve diğerleri } \\
(2015)\end{array}$ & 76 & AG tabanlı öğrenme & $\begin{array}{l}\text { İnsan rehberli geleneksel } \\
\text { ögrrenme }\end{array}$ \\
\hline $\begin{array}{l}\text { Ibáñez ve diğerleri } \\
\text { (2014) }\end{array}$ & 64 & AG tabanlı öğrenme & Web tabanlı öğrenme \\
\hline $\begin{array}{l}\text { Sommerauer ve } \\
\text { Müller (2014) }\end{array}$ & 101 & AG tabanlı sergi & AG Tabanlı olmayan sergi \\
\hline $\begin{array}{l}\text { Chiang ve diğ erleri } \\
\text { (2014a) }\end{array}$ & 57 & Konum tabanlı $\mathrm{AG}$ & Mobil Uygulama \\
\hline $\begin{array}{l}\text { Zhang ve diğerleri } \\
\text { (2014) }\end{array}$ & 200 & AG tabanlı mobil öğrenme & $\begin{array}{l}\text { Geleneksel içi/dışı aygıtlar ile } \\
\text { öğrenme }\end{array}$ \\
\hline $\begin{array}{l}\text { Chang ve diğ erleri } \\
(2014)\end{array}$ & 135 & AG güdümlü mobil Sistem & $\begin{array}{l}\text { - Ses güdümlü mobil sistem } \\
\text { - Ses güdümsüz mobil sistem }\end{array}$ \\
\hline $\begin{array}{l}\text { Chiang ve diğerleri } \\
(2014 b)\end{array}$ & 57 & AG tabanlı mobil öğrenme & $\begin{array}{l}\text { Geleneksel araştırma tabanlı } \\
\text { mobil öğrenme }\end{array}$ \\
\hline $\begin{array}{l}\text { Wang ve diğerleri } \\
\text { (2014) }\end{array}$ & 40 & AG tabanlı simülasyon & Geleneksel 2D simülasyon \\
\hline $\begin{array}{l}\text { DiSerio ve diğerleri } \\
\text { (2013) }\end{array}$ & 69 & AG tabanlı öğrenme & Slayt tabanlı öğrenme \\
\hline $\begin{array}{l}\text { Wojciechowski ve } \\
\text { Cellary (2013) }\end{array}$ & 42 & 3D resim-tabanlı $\mathrm{AG}$ & Geleneksel öğrenme \\
\hline $\begin{array}{l}\text { Lin ve diğerleri } \\
(2013)\end{array}$ & 40 & Mobil AG simülasyon sistemi & $\begin{array}{l}\text { Geleneksel 2D simülasyon } \\
\text { sistemi }\end{array}$ \\
\hline Chen ve Tsai (2012) & 116 & $\begin{array}{l}\text { AG tabanlı kütüphane anlatım } \\
\text { sistemi }\end{array}$ & $\begin{array}{l}\text { Geleneksel kütüphane anlatım } \\
\text { sistemi }\end{array}$ \\
\hline $\begin{array}{l}\text { Tsai ve diğerleri } \\
\text { (2013) }\end{array}$ & 6 & AG tabanlı kaçış yönergeleri & $\begin{array}{l}\text { e-Maps tabanlı kaçış } \\
\text { yönergeleri }\end{array}$ \\
\hline $\begin{array}{l}\text { Yoon ve diğerleri } \\
(2012)\end{array}$ & 119 & $\begin{array}{l}\text { AG tabanlı yapı iskelesi } \\
\text { (scaffolds) }\end{array}$ & $\begin{array}{l}\text { - AG tabanlı olmayan yapı } \\
\text { iskelesi } \\
\text { - Geleneksel öğrenme }\end{array}$ \\
\hline $\begin{array}{l}\text { Hsiao ve diğerleri } \\
(2012)\end{array}$ & 1211 & AG tabanlı öğrenme & $\begin{array}{l}\text { - Bilgisayar destekli ve } \\
\text { gelenekselöğrenme }\end{array}$ \\
\hline
\end{tabular}




\section{Çalışmalarda AG ile İlgili Rapor Edilen Faydalar ve Karşılaşılan Zorluklar}

Ele alınan deneysel çalışmaların çoğu bu teknolojinin uygulandığı ortamlarda görmüş oldukları birtakım faydalardan bahsetmişlerdir. Rapor edilen bu faydalar Tablo 9' da verilmektedir. Burada birden çok çalışma aynı faydayı rapor edebildiğinden dolayı bir çalışma tabloda birden çok fayda için de belirtilmiş olabilmektedir. İncelenen çalışmalarda en çok AG'nin dikkati artırmada (örn., Chiang ve diğerleri, 2014b; DiSerio ve diğerleri, 2013; Ibáñez ve diğerleri, 2014; Ke ve Hsu, 2015; Wojciechowski ve Cellary, 2013) konuları anlamada (örn., Chen ve Tsai, 2012; Ibáñez ve diğerleri, 2014; Ke ve Hsu, 2015; Hsiao ve diğerleri, 2016; Yoon ve diğerleri, 2012) ve öğrenmeye olan istekliliği artırmada (örn., Chang ve diğerleri, 2014; Chen ve Tsai, 2012; Wei ve diğerleri, 2015; Wojciechowski ve Cellary, 2013) öğrencilere yardımcı olduğu rapor edilmiştir. Tablo 9'da belirtilen diğer faydaların oldukça çeşitlilik gösterdiği görülmektedir.

Tablo 9

İncelenen deneysel çalışmalarda AG kullanımına yönelik rapor edilen faydalar

\begin{tabular}{lc}
\hline Faydalar & Çalışma \\
Sayıs (f) \\
\hline Dikkati artırmaya yardımcı olma & 6 \\
Konuyu anlamada yardımcı olma & 5 \\
Öğrenmeye olan istekliliği artırma & 4 \\
Görev üzerine yoğunlaşmayı (konsantrasyonu) artırma & 3 \\
Akış deneyimini artırma & 3 \\
Bilgiyi yapılandırmaya yardımcı olma & 3 \\
İşbirlikçi çalışmayı güçlendirme & 3 \\
İnteraktif katılım sağlama & 3 \\
Hafizayı Güçlendirme & 3 \\
Kavramsal gelişime katkı sağlama & 3 \\
Eğlence duygusunu artırma & 2 \\
Daha az bilişsel çaba sarf etme & 2 \\
Öğrenci merkezli aktivitelerde kolaylık sağlama & 2 \\
Güvenli deney yapma imkânı sağlama & 2 \\
Uygulama becerilerini artırma & 2 \\
Düşünme becerilerini artırma & 1 \\
Güven duygusunu artırma & 1 \\
Keşfedici öğrenmeye katkı & 1 \\
Mekân duygusunu artırma & 1 \\
Yaratıcı tasarım süreçlerine katkı & 1 \\
Gerçeklik duygusunu artırma & 1 \\
Farklı öğrenme stilleri ile başa çıkma & 1 \\
İçeriği ilgi çekici kılma & 1 \\
Düşük maliyetli deney yapma imkânı & 1 \\
Yeniden kullanılabilirlik imkânı sağlama & 1 \\
Hızlı geri dönüt verme & 1 \\
Çevre ile duyusal deneyim sağlama & 1 \\
Gerçek zamanlı etkileşim sağlama & 1 \\
Etkili bilişsel yükü (germane) artırma ve böylece bilgiyi & \\
uzun süreli bellekte saklamayı kolaylaştırma & \\
\hline
\end{tabular}

Tablo 10'da incelenen çalışmaların AG kullanımına yönelik rapor ettikleri birtakım zorluklar yer almaktadır. Çalışmalar en çok işaretleyicilerin (marker) kullanımına yönelik yaşanan zorlukları (örn., Chang ve diğerleri, 2014; Chang ve diğerleri, 2015; Ibáñez ve diğerleri, 2014; Ke ve Hsu, 2015; Sommerauer ve Müller, 2014) ve tabletleri taşıma zorluklarını (örn., 
Chang ve diğerleri, 2014; Chang ve diğerleri, 2015; Ibáñez ve diğerleri, 2014; Sommerauer ve Müller, 2014) rapor etmişlerdir.

AG'nin kullanımına yönelik problemlerin başında, AG sistemlerinin işaretleyicileri tanımlayamama sorunu gelmektedir. Öyle ki bir çalışma (Ibáñez ve diğerleri, 2014) işaretleyici tanımlama sorununu, karşılaştıkları en yaygın problem olarak belirtmiştir. Diğer bazı çalışmalarda işaretleyici tanımlama sorununa yönelik rapor edilenler şunlardır; tableti sallarken AG içeriğinin kaybolması (Chang ve diğerleri, 2014; Ke ve Hsu, 2015; Sommerauer ve Müller, 2014), kameraların ışığa karşı duyarlılık sorunları (Chang ve diğerleri, 2015) ve AG uygulamasını durdurmak veya AG nesnesine olan odaklamayı yok etmek için tableti sallama gerekliliği (Sommerauer ve Müller, 2014). Bazı işaretleyicilerin dış ortam şartlarından (örn., halka açık toplu kullanım alanları) korunması gereklidir. Bu durumda işaretleyicilerin AG görüntüleme aygıtları tarafindan teşhis edilebilirliği bu koruyucu yüzey yüzünden zorlaşmaktadır. Örneğin Chang ve diğerleri (2014) çalışmasında, işaretleyicilerin cam çerçeve içinde olmasından dolayı AG sistemleri tarafından tanımlanamadıklarından söz etmektedir.

AG uygulamalarını yönetirken mobil telefonlara göre daha ağır olan tabletleri elle tutma gerekliliği de bu teknolojiyi kullanırken yaşanan zorlukların en önde gelenlerinden bir tanesidir. Özellikle AG ile ilgili bazı müze çalışmalarında (örn., Sommerauer ve Müller, 2014; Chang ve diğerleri, 2014) katılımcılar, müzeyi gezerken tabletleri yanlarında taşımaları gerektiğini ve işaretleyicileri tanımlayabilmek için tabletleri kaldırıp indirmek zorunda kaldıklarını belirtmişlerdir. Konum tabanlı AG uygulamalarında ise (örn., Harley, Poitras, Jarrell, Duffy ve Lajoie, 2016) yine benzer zorluklar yaşanabilmektedir. Öyle ki etraftaki gerçek varlıklar üzerine bindirilmiş dijital AG nesnelerini görmek isteyen kullanıcılar için AG aygıtları gezinti esnasında bir yük teşkil edebilmektedir.

Bunların dışında çalışmalarda rapor edilen bazı önemli sorunlar şunlardır; AG uygulamalarını görüntüleme esnasında, hem tabletleri hem de fiziksel bileşenleri (örn., kitap, çalışma yaprăg $1 \mathrm{vb}$.) aynı anda elde tutma gerekliliği, AG uygulamasını kullanan öğrencilerin uygulama sırasında benzer özelliklere sahip tabletlere sahip olmaması, AG içeriğini görüntüleme aygıtlarının/ ekipmanların yüksek maliyetli olması, cihazların AG ortamı için hazırlanması sırasında öğrencilerin zorluklar yaşaması, öğrenmede bu tür ürünleri kullanma konusunda aile baskısı yaşanması, genellikle tabletleri okul veya evlerinde kullanmaya alışı olan öğrencilerin özellikle konum tabanlı AG cihazlarını dış ortamlarda kullanmaya alışık olmamaları.

Tablo 10

İncelenen deneysel çalışmalarda, AG kullanımına yönelik rapor edilen zorluklar

\begin{tabular}{lc}
\hline Zorluklar & Çalışma \\
Sayıs (f)
\end{tabular}




\section{Çalışmalarda Ele Alınan AG Uygulamalarının Türü ve İçeriği}

Tablo 11'de, incelenen deneysel çalışmalarda tercih edilen AG türleri verilmiştir. Tablo incelendiğinde bu çalışmaların \%48'lik oranla en çok işaretleyici (marker) tabanlı uygulamaları tercih ettiği görülmektedir. Bunu konum tabanlı(\%40) AG uygulamaları takip etmektedir. Bu iki AG türü yıllardan beri oldukça yaygın kullanılagelmiş̧tir. İki deneysel çalışmanın tercih ettiği dijital ogmentasyonların [fiziksel bir ortam üzerine bilgisayar üretimli resimleri yerleştirme yöntemi (Yoon ve diğerleri, 2012)] kullanımının \%8'lik bir oranla oldukça az olduğu göze çarpmaktadır. Çalışmaların \%4’ü kullandıkları AG türünü belirtmemiştir.

Tablo 11

İncelenen deneysel çalışmalarda kullanılan AG türleri

\begin{tabular}{|c|c|c|}
\hline Kullanılan AG türü & Çalışma Sayısı (f) & Yüzde $(\%)$ \\
\hline İşaretleyici (marker) tabanlı & 12 & 48,00 \\
\hline Konum Tabanlı & 10 & 40,00 \\
\hline Dijital ogmentasyon (augmentation) & 2 & 8,00 \\
\hline Belirtilmemiş & 1 & 4,00 \\
\hline & 22 & 100 \\
\hline
\end{tabular}

Tablo 12'de, incelenen deneysel çalışmalarda kullanılan yazılımlar yer almaktadır. Çalışmaların büyük çoğunluğu (\%72) AG uygulamalarını geliştirirken kullandıkları yazılımlardan bahsetmemiştir. Sadece yedi çalışma kullandıkları yazılımlardan (Aurasma Studio, Vuforia, AR Creative-Builder, OpenGL ES, AR Physics, FLAR Tool Kit, Papervision 3D ve Serproxy) bahsetmiştir.

Tablo 12

İncelenen deneysel çalışmalarda AG geliştirmeye yönelik kullanılan yazılımlar

\begin{tabular}{|c|c|c|}
\hline Kullanılan Yazılım & Çalışma Sayısı (f) & Yüzde $(\%)$ \\
\hline Aurasma Studio & 2 & 8 \\
\hline Vuforia & 1 & 4 \\
\hline AR Creative-Builder & 1 & 4 \\
\hline FLAR Tool Kit, Papervision 3D ve Serproxy & 1 & 4 \\
\hline OpenGL ES 2.0 & 1 & 4 \\
\hline AR Physics & 1 & 4 \\
\hline Belirtilmemiş & 18 & 72 \\
\hline Toplam & 25 & 100 \\
\hline
\end{tabular}

Tablo 13'de, ele alınan deneysel çalışmalarda kullanılan görüntüleme aygıtları/ortamları verilmiştir. Gerçek dünya nesneleri üzerine bindirilen dijital AG nesnelerini görüntülemek üzere araştırmacıların tercih ettiği görüntüleme aygıtlarının en çok tabletler (\%48) olduğu görülmektedir. Bunu sirasıyla bilgisayar + web kamera (\%28) ve mobil telefonlar (\%20) takip etmektedir. AG'yi görüntüleme ortamı olarak bir çalışma (Yoon ve diğerleri, 2012) ise yapı iskeleti kullanmayı tercih etmiştir.

Tablo 13

İncelenen çalışmalarda AG'yi görüntüleme aygıtları

\begin{tabular}{|c|c|c|}
\hline AG'yi Görüntüleme Aygıtı/ Ortamı & Çalışma Sayısı (f) & Yüzde $(\%)$ \\
\hline Tablet & 12 & 48 \\
\hline Web kamera+ Bilgisayar & 7 & 28 \\
\hline Mobil telefon & 5 & 20 \\
\hline AG tabanlı yap 1 iskeleti & 1 & 4 \\
\hline & 25 & 100 \\
\hline
\end{tabular}


Tablo 14'de ele alınan deneysel çalışmalarda kullanılan öğrenme içerikleri verilmektedir. Tablodan görüldüğü üzere çalışmalar en çok 2D nesneleri/ açıklamaları tercih etmiştir. Bunu sirasiyla 3D nesneler/ sanal karakterler takip etmektedir. Video, animasyon ve sesli bilgilerin AG içeriği olarak kullanımın en az olduğu göze çarpmaktadır.

Tablo 14

İncelenen çalışmalarda kullanılan AG içeriğinin türü

\begin{tabular}{lc}
\hline Kullanılan AG İçeriği & Çalışma Sayısı (f) \\
\hline 2D nesneler/açılayıcı metinler & 17 \\
3D nesneler/ sanal karakterler & 13 \\
Video & 1 \\
Animasyon & 1 \\
Sesli bilgi & 2 \\
Belirtilmemiş & 2 \\
\hline
\end{tabular}

\section{Tartışma ve Sonuç}

$\mathrm{Bu}$ araştırmada, literatürde AG üzerine yapılan ve saygın dergilerde yayınlanmış deneysel çalışmalar incelenerek AG destekli öğrenme ortamlarının, AG destekli olmayan diğer öğrenme ortamlarına kıyasla öğrencilerin öğrenme süreçlerini nasıl etkilediğine yönelik bulgular tartışılmıştır. Ayrıca bu öğrenme süreçlerini destekleyecek yeni AG tasarımlarına yönelik çıkarsamalarda bulunulmuştur. Araştırmanın amacı ve belirlenen özel kriterler doğrultusunda SSCI'da taranan 25 deneysel çalışma içerik analiz metodu kullanılarak analiz edilmiştir. Bu çalışmalara yönelik bulguları analiz etmek üzere ele alınan faktörler şunlardır; "eğitim alanı", "hedef kitlenin eğitim seviyesi”, "bağımlı değişkenler", “AG’nin öğrenmede etkililiği”, "AG’nin eğitim ve öğretim ortamlarında kullanımına yönelik faydalar", "AG uygulamalarında karşılaşılan zorluklar", "kullanılan AG türü ve içeriğì", "ihtiyaç duyulan yazılımlar ve görüntüleme aygıtları".

Analiz sonucunda, incelenen deneysel çalışmaların çoğunun Doğa bilimleri, matematik ve istatistik eğitim-öğretim alanında yoğunlaştığı görülmektedir. $\mathrm{Bu}$ alanda yer alan alt bilim dallarında (fizik, kimya, biyoloji, matematik ve ekoloji) öğrencilerin anlamakta zorlandıkları soyut kavramların oldukça fazla olması ve AG teknolojilerinin bu soyut kavramları somutlaştırmaya imkan sağlama yeteneği, bu yoğunluğun asıl sebeplerinden biri olarak görülebilir. AG, öğrencilerin özelleştirilmiş bir aygıt olmadan gerçek dünyada görmeleri mümkün olmayan olayları görebilmelerine imkan sağlayan aktivitelerde etkili olabilmektedir (Bacca ve diğerleri, 2014). Örneğin bir fizik dersinde "manyetizma" konusu işlendiğinde, üzerinden akım geçen bir telin etrafındaki manyetik alanın öğrenciler tarafindan herhangi bir deney seti ile gözlenmesi mümkün olmayabilir. Oysa ki bu manyetik olay, dijital ve üç boyutlu olarak modellenebilir vebu model öğrencinin öğrenme ortamı üzerinde (kitap, çalışma yaprakları, masa vb.) AG teknolojisini destekleyen çeşitli aygıtlar (mobil telefon, tablet vb.) yardımıyla görüntülenebilir. İncelenen çalışmalar arasında, "sosyal bilimler, gazetecilik ve enformasyon", "mühendislik, imalat ve inșaat", "sanat ve beșeri bilimler", "eğitim" ve "hizmetler" alanlarında AG'nin etkililiğini tartışan çok az deneysel çalışmanın yapıldığı, "işletme, yöneticilik ve hukuk", "bilgi ve iletişim teknolojileri", "tarım, ormancılık, balıkçılık ve veterinerlik" ve "sağlık ve sosyal yardımlaşma" gibi alanlarda ise hiç yapılmadığı görülmüştür. Bacca ve diğerleri (2014)'de çalışmalarında sağlık, öğretmen eğitimi ve tarımın, AG açısından az keşfedilen araştırma alanları olduğu sonucuna ulaşmışlardır. Bu alanlardan bazılarında (örn., işletme, yöneticilik, hukuk) AG ile somutlaştırılabilecek kavramların sıklıkla bulunmayışı bu yöndeki çalışmaların yapılmasına imkan sağlamamış olabilir. AG yerine sanal gerçeklik ile ilgili yapılacak uygulamalar bu alanlardaki kavramların somutlaştırılmasında ve anlaşılabilirliğini kolaylaştırmada faydalı olabilir. Sonuç olarak bu alanlarda, diğer öğrenme ortamlarına göre AG’nin etkililiğini araştıran ileriki çalışmalara ihtiyaç olduğu söylenebilir. AG'nin etkileşimli öğrenme ortamlarına imkân sağlayabiliyor olması, özellikle "bilgi ve iletişim teknolojileri", "tarım, ormancılık, balıkçılık ve veterinerlik" ve "sağlık ve sosyal yardımlaşma" gibi alanlardaki öğrencilere öğrenme bağlamında 
büyük avantajlar sağlayabilir. Bu alanlarda $A G$, öğrencilerin imkânsız, tehlikeli veya pahalı deneyleri gerçek ortamlarındaymış gibi yapmalarına olanak sağlayarak aktif öğrenmenin gerçekleşmesine yardımcı olabilir ve böylece öğrenmede kalıcılık sağlanabilir. Gelecekte bu eğitim ve öğretim alanlarında AG'nin etkililiğine yönelik araştırmaları gerçekleştirmenin ve bu alanlarda AG kullanımına yönelik gerekli stratejileri belirlemenin oldukça faydalı olabileceği söylenebilir.

Ele alınan deneysel çalışmaların en çok ortaöğretim seviyelerindeki katılımcılarla gerçekleştirilmiş olduğu, bunu sırasıyla lisans ve ilköğretim düzeylerinin izlediği görülmüştür. $\mathrm{Bu}$ çalışmalar arasında lise, ön lisans, yüksek lisans ve doktora seviyelerinde eğitim gören katılımcılar ile AG'nin etkililiği üzerine yapılan deneysel çalışmalara rastlanmamıştır. Bacca ve diğerlerinin (2014) de çalışmalarında belirttiği üzere, AG üzerine yapılan çalışmaların genellikle yüksek lisans veya doktora seviyesindeki öğrenciler tarafindan gerçekleştirilmiş olma ihtimali, bu iki hedef kitlenin bu alandaki çalışmalarda katılımcı olarak yer almamasının sebepleri arasında yer alabilir. Bahsedilen diğer eğitim seviyelerindeki katılımcılar ile AG'nin etkililiğini araştıracak çalışmalara gereksinim duyulduğu söylenebilir. Etkileşimli öğrenme ortamlarına imkan sağlayabiliyor olması nedeniyle AG teknolojisi, özellikle mesleki derslerin ağırlıklı olduğu ön lisans seviyesindeki öğrenciler için denemesi imkânsız, tehlikeli veya pahalı deneyleri gerçek ortamlarındaymış gibi yapmalarına olanak sağlayabilir.

İncelenen çalışmaların analizleri sonucunda, AG’nin öğrenmede etkisinin en çok araştırıldığı bağımlı değişkenin öğrenme performansı olduğu ve bu çalışmaların çoğunun AG'yi bu değişken üzerinde etkili bulduğu sonucuna ulaşılmıştır (Tablo 7). Öyle ki birçok çalışma (Tablo 9) deney ortamlarında gözlemlediği AG'nin birçok faydasına (örn., dikkati artırma, konuyu anlamaya yardımcı olma, öğrenme istekliliğini, konsantrasyonu, eğlence duygusunu ve akış deneyimini artırma, bilgiyi yapılandırmaya yardımcı olma ve interaktif katılım sağlama vb.) değinmiştir. Öğrencilerin öğrenme performanslarındaki artışa sebep olan etkenler arasında bu faydaların yer aldığı söylenebilir. Tablo 7'den görüldüğü üzere, AG'nin öğrenmede etkisinin en çok araştırıldığ bağımlı değişken olarak motivasyon ikinci sırada yer almaktadır. Motivasyon belirli bir konuda sarf edilen bir çabanın göstergesi ve belirli bir davranışın yönü ve büyüklüğü olarak tanımlanır (Keller, 1983). Bu yüzden öğrenmede motivasyon oldukça önemli bir etkendir ve çevreye bakılmaksızın öğrenme ve motivasyon birbirini tamamlayan iki kavram olarak karşımıza çıkmaktadır (Schunk, 1996). AG'nin öğrenmede etkisinin motivasyon bağlamında araştırıldığı deneysel araştırmalar öğrenme performansına oranla oldukça azınlıkta kalmıştır. Akış deneyimi, davranış biçimleri, duygusal etki, memnuniyet ve tutum gibi diğer bağımlı değişkenler bağlamında da AG'nin etkililiğine yönelik araştırmalara ağırlık verilmesinde fayda olduğu görülmüştür. Diğer taraftan gelecekte yapılması planlanan deneysel çalışmaların; bilişsel stiller, mücadele beceri algıları, teknolojik pedagojik alan bilgisi ve uzamsal yetenekler gibi öğrencilerin kişisel özellikleri üzerinde odaklanmalarında fayda olacağı söylenebilir.

Tablo 8'den görüldüğü üzere AG'nin etkililiğini araştırmak üzere deney ve kontrol grupları için ele alınan AG tabanlı veya AG tabanlı olmayan öğrenme ortamları çeşitlilik göstermektedir. $\mathrm{Bu}$ çalışmalardan çoğu AG tabanlı öğrenme ortamlarını geleneksel olarak kabul edilen diğer öğrenme ortamları ile kıyaslamayı tercih etmiştir. Günümüzde sarmalayıcı sanal gerçeklik (SSG) uygulamalarının eğitim ve öğretim ortamlarında kullanımına yönelik etkililiğini araştıran çalışmalara da (örn., Passig, Tzuriel ve Eshel-Kedmi, 2016; Webster, 2016) rastlamak mümkündür. Fakat incelenen çalışmalar arasında AG'yi bu SSG ortamları ile öğrenme bağlamında kıyaslayan deneysel çalışmalara hiç rastlanmamıştır. SSG cihazlarının (örn., Gear VR, Oculus vb.) daha yeni yaygınlaşmaya başlamış olması, bu cihazların maliyetlerinin nispeten yüksek olması ve her katılımcıya bu cihazları kullandırma gerekliliği, araştırmacıların deneysel koşulları hazırlamalarında zorluklar yaşamalarına sebep olmuş olabilir. İlerideki çalışmaların bu konuyu ele almaları, öğretim tasarımcıları ve eğitmenlerin AG ve SSG bağlamında öğrenme ortamları için en etkili teknolojiyi seçmelerine olanak sağlayabilecektir.

Yine Tablo 8'de verilen çalışmalar örneklem sayıları bakımından değerlendirildiğinde genellikle 0-29 arası örneklem sayısı ile çalışan iki, 30-59 arası örneklem sayısı ile çalışan 10, 6099 arası örneklem sayısı ile çalışan altı ve 100 üzeri örneklem sayısı ile çalışan yedi deneysel 
araştırmanın olduğu görülmektedir. Az sayıda örneklem ile çalışmanın olası sebeplerinden birisi, AG uygulamalarını görüntüleme aygitlarının hala yeterince ucuz olmaması ve her katılımcıya bu cihazları kullandırma gerekliliği olabilir. Deneysel koşulların hazırlanmasında grup içi veya gruplar arası fiziksel koşulların çok dikkatli hazırlanması ve iki veya daha fazla yöntemin uygulandığı ortamlarda tüm koşulların eşitlenmesi, araştırmaların iç ve dış geçerlilikleri bağlamında oldukça önemlidir (Karasar, 2004). AG'ye yönelik deneysel çalışmalarda AG uygulamalarını deneyen katılımcılara eşit özelliklere sahip AG görüntüme aygıtlarının (örn., tablet, mobil telefon) verilmesi AG destekli ortamların diğer öğrenme ortamlarına göre etkililiğini doğru bir şekilde ortaya çıkarmada fayda sağlayacaktır.

İncelenen deneysel çalışmaların AG'ye yönelik rapor ettiği faydalar Tablo 9'da verilmektedir. Dikkati artırmaya yardımcı olma, konuyu anlamaya yardımcı olma ve öğrenmeye olan istekliliği artırma bu rapor edilen faydalar arasında üst sıralarda yer almaktadır. Bu teknolojilerin yeni gelişmekte olması, çoğu öğrencinin bu teknoloji ile daha önce hiç karşılaşmamış olmaları ve bu teknolojinin sınıf ortamlarına yeni girmeye başlıyor olması öğrencilerdeki bu dikkat ve istekliliğin kaynağı olabilir. Fakat şu da göz önünde bulundurulmalıdır ki teknoloji ile iç içe büyüyen yeni neslin bu tür teknolojilere yönelik ilgileri ve dikkatleri zamanla kaybolabilmektedir. İsteklilik ve dikkati sürdürme bağlamında yapılacak ilerideki çalışmalar bu yönde bize bazı göstergeler sunabilir. AG teknolojilerinin soyut kavramları somutlaştırma ve etkileşimli ortamlar sunabilme özelliği ise öğrencilerin konuları anlamalarına yardımcı olmuş olabilir.

Ele alınan çalışmalarda AG'ye yönelik rapor edilen zorluklar arasında (Tablo 10) işaretleyicilere (marker) yönelik yaşanan problemler üst sırada yer almaktadır. Bu problemin yaygınlığı görüntü işleme tekniklerinin AG ile ilgili uygulamalar açısından daha fazla gelişme göstermesi gerekliliğini ortaya çıkarmaktadır. Görüntü işleme ile ilgili bu tür sorunları ortadan kaldıracak çalışmaların artırılmasında fayda olacağı söylenebilir. Zorluklar açısından ikinci sırada AG uygulamalarını kullanma sirasında mobil telefonlara göre daha ağır olan tabletleri elle tutma güçlükleri yer almaktadır. Bu cihazlar yerine daha hafif olabilen ve kafaya takılabilen Google Cardboard kullanımı çözüm yollarından biri olabilir. Bir çalışmada (Ibáñez ve diğerleri, 2014), AG uygulamalarını görüntülerken hem tabletleri hem de fiziksel bileşenleri aynı anda kullanma zorunluluğu bir sorun olarak görülmüştür. İşaretleyici tabanlı AG uygulamalarını kullanırken tabletlerin bir yüzeye veya kullanıcıya sabitlenmesi bu sorunu ortadan kaldırmak için bir çözüm yolu olabilir. Ancak bu durumlarda da bazı kullanışlılık sorunlarının ortaya çıkması muhtemeldir. 2D, 3D, video ve ses gibi dijital öğrenme materyallerinin hazırlanma ve öğrenme süreçlerini geliştirme zamanının uzun olması ve bu materyallerin dosya boyutuna yönelik sınırlamalar da çalışmaların rapor ettiği bir başka sorundur. Bu materyaller arasından 3D olanların geliştirilmesi için hem yetenek hem de zaman gereksinimi oldukça yüksektir. Var olan 3D materyaller ise bazı ticari internet sitelerinden indirilebilir. Fakat bu materyallerin maliyeti bazen oldukça yüksek olabilmektedir. Özellikle 3D uygulamalar, video ve ses içerikleri, bir AG uygulaması içinde dosya boyutu bakımından oldukça yer kaplayabilmektedir. Bu da büyük çaplı AG uygulamaları için büyük bir sorun teşkil edebilmektedir. Bu sorunun üstesinden gelebilmek için AG uygulaması bulut tabanlı bir uygulama ile ilişkilendirilebilir. Başka bir zorluk konum tabanlı uygulamalar ile ilgili rapor edilmiştir. Bir çalışmada (Chiang ve diğerleri, 2014) mobil cihazların GPS doğruluğuna yönelik bazı sıkıntılarından dolayı öğrenme nesnelerinin yerinin doğru görüntülenemediği belirtilmektedir. Klasik ölçme yöntemlerinde olduğu gibi GPS doğruluğuna etki eden birçok faktör (örn., çevresel faktörler, erişilen uydu sayısı, sabit alıcıdan olan uzaklık, mobil GPS alıcısının kalitesi) bulunmaktadır (Yalçın, İnal, Kalaycı ve Tarihi 2008). Bu nedenle öğrenme nesnelerinin boyutunu ve aralarındaki mesafeyi dikkate almak gerekir (Chiang ve diğerleri, 2014). Konum tabanlı bir AG aygıtını kullanırken bu tür sorunların üstesinden gelebilmenin bazı durumlarda nerdeyse imkânsız olduğu söylenebilir.

Ele alınan çalışmalarda çoğunlukla işaretleyici (marker) tabanlı uygulamaların tercih edildiği görülmektedir. Konum tabanlı AG uygulamaları ise bu tercih sıralamasında ikincidir. Bu bulgular Bacca ve diğerlerinin (2014) bulguları ile paralellik göstermektedir. İşaretleyici ve konum tabanlı AG türleri yıllardan beri oldukça yaygın kullanılmaktadır. Çok yakında Hololens 
gibi aygıtların getireceği yeniliklerin, işaretleyici ve konum tabanlı uygulamaların kullanımını geride bırakabileceği öngörülmektedir. Bu aygıtlar, herhangi bir işaretleyiciye veya konum bilgisine gerek duymadan, dijital nesneleri bulunduğumuz ortamlarda gösterebilmekte ve onlarla ses veya el hareketleri yardımı ile etkileşim kurmaya imkan sağlayabilmektedirler. İleride, AG'nin değişik bir versiyonu olan karma gerçeklik teknolojilerinin eğitim ortamlarında kullanımına yönelik çalışmaların artması söz konusu olabilir. İncelenen çalışmalar arasında AG uygulamalarını geliştirirken kullandıkları yazılımlardan (örn., Aurasma Studio, Vuforia, AR Creative-Builder, Open GL ES, AR Physics, FLAR Tool Kit, Papervision 3D ve Serproxy) söz eden çok az çalışmaya rastlanmıştır. Oysa bu konuda çalışmak isteyen araştırmacılara bu tür uygulamaların nasıl geliştirileceğine veya hangi yazılımların kullanılması gerektiğine yönelik bilgiler vermek, AG'ye yönelik araştırmaların artmasına katkı sağlayabilir. AG kullanımına yönelik deneysel çalışmalarda kullanılan öğrenme içerikleri incelendiğinde en çok 2D öğrenme nesneleri veya açıklayıcı metin öğelerinin tercih edildiği görülmektedir. Bunu sırasıyla 3D nesneler/ sanal karakterler takip etmektedir. Video, animasyon ve sesli bilgilerin kullanımı az tercih edilen AG içeriği olarak karşımıza çıkmaktadır. Fakat günümüzde özellikle geleneksel kitaplar üzerine video veya animasyon içeriklerinin bindirildiği AG uygulamalarına da sıklıkla rastlanmaktadır. $\mathrm{Bu}$ tür uygulamaların öğrenme üzerine etkililiği ileride yapılacak daha çok çalışma ile değerlendirilebilir.

"Son yıllarda ilerleyen teknoloji ile ortaya çıkan AG teknolojilerinin eğitimde kullanım alanları yaygınlaşmakta ve bu teknolojilerin kullanımı kolaylaşmaktadır" (Erbaş ve Demirer, 2014). AG sayesinde bilgi, gerçek kitaplardan sayısal ortama değil, sayısal ortamdan kitaplar gibi gerçek öğrenme ortamlarına aktarılabilmektedir. Özellikle Google Glass, Google Cardboard veya Hololens gibi AG görüntüleme aygıtları sayesinde, yakın gelecekte kitaplarda yer alan durağan bilgilerin, etkileşimli ve üç boyutlu nesnelere, videolara veya sesli bilgilere dönüştürülebileceği ve bunları izlemek/ dinlemek için öğrencilerin internete bile sahip olmasının gerekmeyeceği öngörülmektedir. Bu da öğrencilere AG özelliklerine sahip kitapları her yerde çalışma olanağ sağlayacaktır. Son yıllarda, kamera entegreli mobil sürücüler ve her yerden ulaşılabilen internet erişimindeki gelişmeler sayesinde, akı1lı telefon ve tabletlere sahip olan insanlar AG uygulamalarını rahatlıkla kullanabilir hale gelmiştir. Artık sınıflarımıza kadar girmeyi başarmış olan bu teknolojinin çeşitli alanların (örn., fen, matematik, biyoloji vb.) öğretiminde kullanma potansiyeli araştırılmaya değer görülmüştür. Fakat bu çabaların şu an emekleme aşamasında olduğu söylenebilir.

\section{Araştırmanın Sınırlılıkları}

- İncelenen çalışmalar sadece Web of Science ve Google Akademik arama motorlarındaki taramalar sonucu elde edilmiştir,

- Çalı̧̧mada sadece deney grubu AG destekli, kontrol grubu ise AG destekli olmayan öğrenme ortamlarını veya araçlarını çeşitli pedagojik açılardan kıyaslayan deneysel çalışmalar ele alınmıştır,

- İncelenen çalışmaların yayın yılları 2011-2016 aralığı ile sınırlıdır,

- Ele alınan çalışmaların tümü sadece eğitimde AG’nin kullanımına yöneliktir.

\section{Kaynaklar}

Azuma, R. T. (1997). A survey of augmented reality. Presence: Teleoperators and virtual environments, 6(4), 355-385.

Azuma, R., Baillot, Y., Behringer, R., Feiner, S., Julier, S. ve MacIntyre, B. (2001). Recent advances in augmented reality. IEEE Computer Graphics and Applications, 21(6), 34-47.

Bacca, J., Baldiris, S., Fabregat, R. ve Graf, S. (2014). Augmented reality trends in education: a systematic review of research and applications. Journal of Educational Technology \& Society, 17(4), 133. 
Özdemir

Barsom, E. Z., Graafland, M. ve Schijven, M. P. (2016). Systematic review on the effectiveness of augmented reality applications in medical training. Surgical endoscopy, 30(10), 41744183.

Billinghurst, M., Kato, H. ve Poupyrev, I. (2001). The magic book-moving seamlessly between reality and virtuality. IEEE Computer Graphics and applications, 21(3), 6-8.

Bokyung, K. (2008). Investigation on the relationships among media characteristics, presence, flow, and learning effects in augmented reality based learning. Multimedia and E-Content Trends içinde (ss.. 21-37). Vieweg+ Teubner.

Bower, M., Howe, C., McCredie, N., Robinson, A. ve Grover, D. (2014). Augmented reality in education-cases, places and potentials. Educational Media International, 51(1), 1-15.

Bressler, D. M. ve Bodzin, A. M. (2013). A mixed methods assessment of students' flow experiences during a mobile augmented reality science game. Journal of Computer Assisted Learning, 29(6), 505-517.

Chang, H. Y., Hsu, Y. S. ve Wu, H. K. (2016a). A comparison study of augmented reality versus interactive simulation technology to support student learning of a socio-scientific issue. Interactive Learning Environments, 24(6), 1148-1161.

Chang, K. E., Chang, C. T., Hou, H. T., Sung, Y. T., Chao, H. L. ve Lee, C. M. (2014). Development and behavioral pattern analysis of a mobile guide system with augmented reality for painting appreciation instruction in an art museum. Computers \& Education, 71, 185-197.

Chang, R. C., Chung, L. Y. ve Huang, Y. M. (2016b). Developing an interactive augmented reality system as a complement to plant education and comparing its effectiveness with video learning. Interactive Learning Environments, 24(6), 1245-1264.

Chang, Y. L., Hou, H. T., Pan, C. Y., Sung, Y. T. ve Chang, K. E. (2015). Apply an augmented reality in a mobile guidance to increase sense of place for heritage places. Educational Technology \& Society, 18(2), 166-178.

Chen, C. M. ve Tsai, Y. N. (2012). Interactive augmented reality system for enhancing library instruction in elementary schools. Computers \& Education, 59(2), 638-652.

Chen, C. P. ve Wang, C. H. (2015). Employing augmented-reality-embedded instruction to disperse the imparities of individual differences in earth science learning. Journal of Science Education and Technology, 24(6), 835-847

Chiang, T. H., Yang, S. J. ve Hwang, G. J. (2014a). Students' online interactive patterns in augmented reality-based inquiry activities. Computers \& Education, 78, 97-108.

Chiang, T. H., Yang, S. J. ve Hwang, G. J. (2014b). An augmented reality-based mobile learning system to improve students' learning achievements and motivations in natural science inquiry activities. Educational Technology \& Society, 17(4), 352-365.

Demirer, V. ve Erbaş, Ç. (2015). Mobil artırılmış gerçeklik uygulamalarının incelenmesi ve eğitimsel açıdan değerlendirilmesi. Mersin Üniversitesi Ĕ̆itim Fakültesi Dergisi, 11(3), 802-813.

DiSerio, Á., Ibáñez, M. B. ve Kloos, C. D. (2013). Impact of an augmented reality system on students' motivation for a visual art course. Computers \& Education, 68, 586-596.

Dunleavy, M. ve Dede, C. (2014). Augmented reality teaching and learning. Handbook of research on educational communications and technology içinde (ss. 735-745). Springer New York

Dunleavy, M., Dede, C. ve Mitchell, R. (2009). Affordances and limitations of immersive participatory augmented reality simulations for teaching and learning. Journal of Science Education and Technology, 18(1), 7-22.

Erbaş, Ç. ve Demirer, V. (2014). Eğitimde artırılmış gerçeklik uygulamaları: Google Glass örneği. Journal of Instructional Technologies \& Teacher Education, 3(2), 8-16.

Erbaş, Ç. ve Demirer, V. (2015). Eğitimde sanal ve artırılmış gerçeklik uygulamaları. B. Akkoyunlu, A. İşman ve H. F. Odabaşı (Yay. haz.), Eğitim Teknolojileri Okumaları içinde (s.131-148) 2015. 
Gavish, N., Gutiérrez, T., Webel, S., Rodríguez, J., Peveri, M., Bockholt, U. ve Tecchia, F. (2015). Evaluating virtual reality and augmented reality training for industrial maintenance and assembly tasks. Interactive Learning Environments, 23(6), 778-798.

Harley, J. M., Poitras, E. G., Jarrell, A., Duffy, M. C. ve Lajoie, S. P. (2016). Comparing virtual and location-based augmented reality mobile learning: emotions and learning outcomes. Educational Technology Research and Development, 64(3), 359-388.

Hsiao, H. S., Chang, C. S., Lin, C. Y. ve Wang, Y. Z. (2016). Weather observers: a manipulative augmented reality system for weather simulations at home, in the classroom, and at a museum. Interactive Learning Environments, 24(1), 205-223.

Hsiao, K. F., Chen, N. S. ve Huang, S. Y. (2012). Learning while exercising for science education in augmented reality among adolescents. Interactive Learning Environments, 20(4), 331349.

Huang, T. C., Chen, C. C. ve Chou, Y. W. (2016). Animating eco-education: To see, feel, and discover in an augmented reality-based experiential learning environment. Computers \& Education, 96, 72-82.

Ibáñez, M. B., Di-Serio, Á., Villarán-Molina, D. ve Delgado-Kloos, C. (2014). Experimenting with electromagnetism using augmented reality: Impact on flow student experience and educational effectiveness. Computers \& Education, 71, 1-13.

Karasar, N. (2004). Bilimsel araştırma yöntemi: kavramlar, ilkeler, teknikler. Nobel Yayın Dağıtım.

Ke, F. ve Hsu, Y. C. (2015). Mobile augmented-reality artifact creation as a component of mobile computer-supported collaborative learning. The Internet and Higher Education, 26, 3341.

Keller, J. M. (1983). Motivational design of instruction. Instructional design theories and models: An overview of their current status, 1(1983), 383-434.

Kitchenham, B. (2004). Procedures for performing systematic reviews. Keele, UK, Keele University, 33(2004), 1-26.

Leslie, K. C., Low, R., Jin, P. ve Sweller, J. (2012). Redundancy and expertise reversal effects when using educational technology to learn primary school science. Educational technology research and development, 60(1), 1-13.

Lin, T. J., Duh, H. B. L., Li, N., Wang, H. Y. ve Tsai, C. C. (2013). An investigation of learners' collaborative knowledge construction performances and behavior patterns in an augmented reality simulation system. Computers \& Education, 68, 314-321.

Liou, W. K., Bhagat, K. K. ve Chang, C. Y. (2016). Beyond the flipped classroom: A highly interactive cloud-classroom (HIC) embedded into basic materials science courses. Journal of Science Education and Technology, 25(3), 460-473.

Mayer, R. E. (2002). Multimedia learning. Psychology of learning and motivation, 41, 85-139.

Mayer, R. E. (2005). Principles for reducing extraneous processing in multimedia learning: Coherence, signaling, redundancy, spatial contiguity, and temporal contiguity principles. The Cambridge handbook of multimedia learning, 183-200.

Moreno, R. (2006). Does the modality principle hold for different media? A Test of the method affects learning hypothesis. Journal of Computer Assisted Learning, 22(3), 149-158.

Özdemir, M., İzmirli, S. ve Sahin-İzmirli, O. (2016). The effects of captioning videos on academic achievement and motivation: reconsideration of redundancy principle in instructional videos. Educational Technology \& Society, 19(4), 1-10.

Passig, D., Tzuriel, D. ve Eshel-Kedmi, G. (2016). Improving children's cognitive modifiability by dynamic assessment in 3D Immersive Virtual Reality environments. Computers \& Education, 95, 296-308.

Richards, D. ve Taylor, M. (2015). A Comparison of learning gains when using a 2D simulation tool versus a 3D virtual world: An experiment to find the right representation involving the Marginal Value Theorem. Computers \& Education, 86, 157-171. 
Santos, M. E. C., Chen, A., Taketomi, T., Yamamoto, G., Miyazaki, J. ve Kato, H. (2014). Augmented reality learning experiences: Survey of prototype design and evaluation. Learning Technologies, IEEE Transactions on, 7(1), 38-56.

Satpute, T., Pingale, S. ve Chavan, V. (2015, January). Augmented reality in e-learning review of prototype designs for usability evaluation. Communication, Information \& Computing Technology (ICCICT), 2015 International Conference on içinde (s. 1-4). IEEE.

Schunk, D. H. (1996). Learning theories. New Jersey, NJ: Printice Hall Inc.

Serino, M., Cordrey, K., McLaughlin, L. ve Milanaik, R. L. (2016). Pokémon Go and augmented virtual reality games: a cautionary commentary for parents and pediatricians. Current opinion in pediatrics, 28(5), 673-677.

Sommerauer, P. ve Müller, O. (2014). Augmented reality in informal learning environments: A field experiment in a mathematics exhibition. Computers \& Education, 79, 59-68.

Tsai, M. K., Liu, P. H. E. ve Yau, N. J. (2013). Using electronic maps and augmented realitybased training materials as escape guidelines for nuclear accidents: An explorative case study in Taiwan. British Journal of Educational Technology, 44(1), E18-E21.

UNESCO Institute for Statistics (2015), International Standard Classification of Education fields of education and training 2013 (ISCED-F 2013): detailed field descriptions, International Standard Classification of Education (ISCED), UIS, Montreal, Erişim adresi: http://dx.doi.org/10.15220/978-92-9189-179-5-en

UNESCO Institute for Statistics (2015), Operational Manual: Guidelines for Classifying National Education Programmes and Related Qualifications: ISCED 2011, OECD Publishing, Paris., Erişim adresi: http://dx.doi.org/10.1787/9789264228368-en

Wang, H. Y., Duh, H. B. L., Li, N., Lin, T. J. ve Tsai, C. C. (2014). An investigation of university students' collaborative inquiry learning behaviors in an augmented reality simulation and a traditional simulation. Journal of Science Education and Technology, 23(5), 682-691.

Webster, R. (2016). Declarative knowledge acquisition in immersive virtual learning environments. Interactive Learning Environments, 24(6), 1319-1333.

Wei, X., Weng, D., Liu, Y. ve Wang, Y. (2015). Teaching based on augmented reality for a technical creative design course. Computers \& Education, 81, 221-234.

Wojciechowski, R. ve Cellary, W. (2013). Evaluation of learners' attitude toward learning in ARIES augmented reality environments. Computers \& Education, 68, 570-585.

Wu, H. K., Lee, S. W. Y., Chang, H. Y. ve Liang, J. C. (2013). Current status, opportunities and challenges of augmented reality in education. Computers and Education, 62, 41-49.

Yalçın, B., İnal, C. ve Kalaycı, İ. (2008). GPS ölçü süresinin nokta konum doğruluğu ile ilişkisi. Selcuk University Journal of Engineering, Science and Technology, 23(1), 19-26.

Yllmaz, R. M. (2016). Educational magic toys developed with augmented reality technology for early childhood education. Computers in Human Behavior, 54, 240-248.

Yoon, S. A., Elinich, K., Wang, J., Steinmeier, C. ve Tucker, S. (2012). Using augmented reality and knowledge-building scaffolds to improve learning in a science museum. International Journal of Computer-Supported Collaborative Learning, 7(4), 519-541.

Zhang, J., Sung, Y. T., Hou, H. T. ve Chang, K. E. (2014). The development and evaluation of an augmented reality-based armillary sphere for astronomical observation instruction. Computers \& Education, 73, 178-188.

\section{Extended Abstract}

\section{Introduction}

In recent years, researches on AR technologies are striving to take first place among research trends related to educational technologies. Until now, many studies searched for answers to many questions about how much AR technology increases learning, what advantages it brings, what challenges it brings, and what training areas are appropriate. 


\section{Purpose of study}

In this study; it is aimed to present a systematic review of experimental studies comparing AR based learning environments with non-AR based learning environments. In this context, following factors were evaluated to analyze the findings of how the AR influenced the learning processes; "education field", "education level of target group", "other learning environments in which the effect of AR is compared", "dependent variables", "the effectiveness and benefits of AR", "difficulties encountered in practice", "used AR type and contents", "needed software" and "displaying devices".

\section{Method}

In the study, experimental studies on the use of AR in education published between 2011 and 2016 were discussed. In accordance with the purpose of the research and the determined specific criteria, 25 experimental studies published between 2011 and 2016 and scanned at SSCI were analyzed by using a systematic literature review method. The study was carried out in a threestep process, which compiled from Kitchenham's (2004) study by Bacca et al., (2014); planning, determination of the studies to be examined and reporting. Thus, by examining the AR and education-related experimental studies published in the respectable journals, findings about how AR-supported learning environments affect students' learning processes compared to non-AR based learning environments are discussed.

\section{Results}

Most of the experimental studies (\%56) on AR in education have concentrated in the education area of Natural Sciences, Mathematics and Statistics;

- Six studies (Chen \& Wang, 2015; Hsiao et al., 2012; Ibáñez et al., 2014; Lin et al., 2013; Wang et al., 2014; Zhang et al., 2014) were related to Physic,

- Six studies (Chang et al., 2016a; Chang et al., 2016b; Chiang et al., 2014a; Chiang et al., 2014b; Hsiao et al., 2013; Huang et al., 2016) were conducted on Environment,

- One study was related to Chemistry (Wojciechowski \& Cellary, 2013) and

- One study (Lin et al., 2015) was conducted in the Mathematics.

The $16 \%$ of experimental studies were carried out on Social Sciences, Journalism and Information educational field;

- Three studies (Chang et al., 2014; Yoon et al., 2012; Sommerauer \& Müller, 2014) were conducted on Museum Studies and,

- One study (Chen \& Tsai, 2012) was related to Library studies.

There are very few experimental studies discussing the effectiveness of AR in other teaching and learning areas such as Engineering, manufacturing and construction (Chang et al., 2015; Gavis et al., 2015; Liou et al., 2016), Arts and humanities (Di Serio et al., 2013; Wei et al., 2015), Education (Ha et al., 2015; Ke \& Hsu, 2015), and Services (Tsai et al., 2013).

Experimental studies were generally considered in secondary, primary and undergraduate levels. In addition, there was no experimental study on the effectiveness of AR carried out with the participants in high school, associate degree, postgraduate and doctoral levels. Among the examined studies, learning performance was the most examined dependent variable on which the AR's learning effect. Many of these studies found that AR is effective in improving learning performance of learners in learning environments. Motivation was also in second order.

Most of the studies chose to compare AR-based learning environments with traditional learning environments. Besides, most of the studies worked with a small sample size. Possible reasons for this may be; displaying devices for AR applications are still not cheap enough, and each participant is required to use these devices.

Increasing the attention (eg., Chiang et al., 2014b; DiSerio et al., 2013; Han et al., 2015; Ibáñez et al., 2014; Ke \& Hsu, 2015; Wojciechowski \& Cellary, 2013), increasing the understanding (eg., Chen \& Tsai, 2012; Hsiao et al., 2016; Ibáñez et al., 2014; Ke \& Hsu, 2015; Yoon et al., 2012) and increasing the willingness for learn (eg., Chang et al., 2014; Chen \& Tsai, 2012; Wei et al., 2015; Wojciechowski \& Cellary, 2013) were among the top benefits reported in 
Özdemir

examined studies. Among the reported difficulties for AR in the studies marker problems (eg., Changet al., 2014; Chang et al., 2015; Ibáñez et al., 2014; Ke \& Hsu, 2015; Sommerauer \& Müller, 2014) were at the top. Difficulties of holding the tablets by hand were in the second order (eg., Chang et al., 2014; Chang et al., 2015; Ibáñez et al., 2014; Sommerauer \& Müller, 2014). It seems that majority of the studies preferred the marker-based applications. This was followed by location based AR applications. Few experimental studies referred to software they used while developing AR applications.

\section{Discussion}

Today, the potential to use this technology in teaching of various education fields (eg, science, mathematics, biology, etc.) has been found valuable to investigate by researchers. But these efforts are now in their infancy. This study aimed to provide a strong support for future researches by presenting a systematic review of experimental studies on the effectiveness of AR in educational settings. 